This is the submitted version of the following article: Colón, J., et al. Towards the implementation of new regional biowaste management plans: environmental assessment of different waste management scenarios in Catalonia in Resources, conservation and recycling, vol. 95 (Feb. 2015), p. 143-155, which has been published in final form at DOI 10.1016/j.resconrec.2014.12.012

(C) 2015. This manuscript version is made available under the CC-BY-NC-ND 4.0 license http://creativecommons.org/licenses/by-nc-nd/4.0/ 


\title{
Towards the implementation of new regional biowaste management plans: Environmental Assessment of different waste management scenarios in Catalonia
}

\author{
Joan Colón ${ }^{1}$, Erasmo Cadena ${ }^{1}$, Ana Belen Colazo ${ }^{1}$, Roberto Quirós ${ }^{2}$, Antoni Sánchez ${ }^{1}$, Xavier \\ Font ${ }^{1}$ and Adriana Artola ${ }^{1}$ \\ ${ }^{1}$ Composting Research Group. Department of Chemical Engineering. Universitat Autònoma de \\ Barcelona. Bellaterra, Barcelona (Spain) \\ ${ }^{2}$ SosteniPrA Research Group, Institute of Environmental Science and Technology (ICTA), \\ Universitat Autònoma de Barcelona, 08193 Edifici C Bellaterra (Barcelona), Spain \\ Contact: Joan Colón, Universitat Autònoma de Barcelona, Departament d'Enginyeria Química, Escola \\ d'Enginyeria, Edifici Q, Campus de Bellaterra, 08193- Cerdanyola del Vallès, Spain. Tel.: +34935814793, \\ Fax.: +34935812013, e-mail address: joan.colon@uab.cat
}




\section{Abstract}

In the present work, different scenarios for the treatment of the organic fraction of municipal waste at regional scale are proposed and assessed by means of LCA. The geographical area under study is Catalonia (Spain). The current Catalan waste management scenario treating $1,218 \mathrm{Gg}$ of organic waste is analyzed and compared to a new scenario treating the same amount of waste but fulfilling the European Landfill Directive and the new recently approved Catalan waste management plan. As final disposal (incineration and sanitary landfill) of untreated municipal solid waste is not permitted, the new scenario includes increasing anaerobic digestion treatment of source selected organic fraction of municipal solid waste while maintaining the existing composting plants for this type of waste. Gaseous emissions treatment equipment will be provided when not installed in composting plants. Home composting is also included. Non-source selected organic fraction of municipal solid waste will be treated by composting. Different scenarios for sensitivity analysis have also been proposed dealing with the influence of transport, fugitive methane emissions from anaerobic digestion plants and the use of compost among other issues. The new scenario proposed decreases the impact in 5 out of the 6 impact categories studied (from a $49 \%$ in eutrophication potential to a $9 \%$ in ozone depletion potential). The inclusion of methane fugitive emissions in anaerobic digestion installations in impacts calculation impairs the environmental benefits of this type of treatment facilities (increasing global warming potential value up to a $31 \%$ ). Improvement of landfill gas collection is of utmost importance in decreasing global warming potential. 


\section{Keywords}

Environmental impact, OFMSW treatment, Composting, Anaerobic digestion, Impact potentials, Waste treatment scenarios. 


\section{Abbreviations}

LCA: Life Cycle Assessment

MSW: Municipal Solid Waste

OFMSW: Organic Fraction of Municipal Solid Waste

SS-OFMSW: Source-Selected Organic Fraction of Municipal Solid Waste

NSS-OFMSW: Non Source-Selected Organic Fraction of Municipal Solid Waste

VOC: Volatile Organic Compounds

Waste Treatments:

AD: Anaerobic Digestion

AWB: Aerated Windrows Composting with gaseous emissions Biofiltration

AWC: Aerated Windrows Composting

CT: In-vessel Composting

HC: Home Composting

TWC: Turned Windrows Composting

Impact potentials:

ADP: Abiotic Depletion Potential

AP: Acidification Potential

EUP: Eutrophication Potential

GWP: Global Warming Potential

OLDP: Ozone Layer Depletion Potential

POP: Photochemical Oxidation Potential 


\section{Introduction}

Waste management operations including collection, valorization and/or treatment and disposal have suffered continuous changes within the last decades evolving from the simple form of collection and dumping to integrated solid waste management practices under a defined waste hierarchy and sustainability principles. Assessment of environmental, social and economic costs and benefits of the different waste management options is of growing interest. Thomas and McDougall (2005), members of the international expert group on life cycle assessment for integrated waste management, pointed Life Cycle Assessment (LCA) as an adequate tool to assess the overall environmental burdens of waste management proposals.

Clift et al. (2000) presented a methodology for LCA application to integrated solid waste management on the light of the European Directive on Integrated Pollution Prevention and Control published in 1996 (and revised in 2008, Directive 2008/1/EC), which introduced in the European Union Member States legislation the need of considering industrial and other activities from a global point of view, including activities upstream and downstream the studied process. Laurent et al. (2014), who undertook a huge review of LCA studies on solid waste management systems, also highlight the strong dependence of the results reported on the local specificities. These authors conclude that, with exception of landfilling, with a poor environmental performance, there is no agreement among LCA results on the best treatment for organics, plastic, paper and mixed municipal solid waste. However, these authors recommend stakeholders in waste management to consider LCA as a tool to identify critical problems and strong aspects of the proposed options. Also, Cleary (2009) presented a wide review in this field, mainly regarding methodological aspects and concluding that the inventory data used in LCA play an 
important role in results dispersion, also influenced by the unclear definition of system boundaries, methodological assumptions made or the different objectives of the studies.

There are a significant number of papers on LCA of waste management systems applied at local or regional level, mainly comprising municipal solid waste (MSW). This is the case of Arena et al. (2003) who used LCA to quantify the relative advantages and disadvantages of different waste management schemes proposed in the Campania region (South Italy) or the work of Banar et al. (2009) in relation to MSW management in Eskisehir (Turkey), where alternatives should be proposed to the actual practice of dumping MSW in a landfill with neither liner nor biogas collection. Björklund and Finnveden (2007) also applied LCA in Sweden relating waste incineration in a Strategic Environmental Assessment (SEA) framework. Bovea et al. (2010) defined a large number of alternative MSW management strategies including collection systems, treatment and final disposal in a medium size Spanish municipality. Also, Fernández-Nava et al. (2014) presented different scenarios considering energy recovery options from MSW in Asturias (North of Spain).

Legislative restrictions in waste management and treatment should be taken into account in scenarios proposal. Finnveden et al. (2009) reported different types of LCA scenarios depending on the type of question they were aimed to answer. Normative scenarios are those arising on how a specific target can be reached. The European Union Council Landfill Directive (99/31/CE) requires EU Member States to reduce the quantity of biodegradable waste ending up untreated in landfill sites by adopting measures to increase and improve waste reduction, recovery and recycling. In the particular case of the organic fraction of municipal solid waste (OFMSW), suitable valorization technologies proposed are composting and anaerobic digestion (European Commission, 1999). Composting (at industrial or home scale) produces a final material (compost) that 
can be used as soil amendment while anaerobic digestion stabilizes the waste organic matter ending up with a gas flow with a methane content of 60-70\% (biogas) and a sludge also with soil improvement properties (Colón et al., 2012). Gaseous emissions in form of volatile organic compounds, methane $\left(\mathrm{CH}_{4}\right)$, nitrous oxide $\left(\mathrm{N}_{2} \mathrm{O}\right)$ and ammonia $\left(\mathrm{NH}_{3}\right)$ are considered as the main cause of the impacts of the composting process as well as its energy consumption (Colón et al., 2012). In the case of anaerobic digestion, gaseous emissions are lower than those of composting because anaerobic digestion takes place in closed reactors. In addition, energy recovery from the produced biowaste delivers a net positive production of energy thus contributing to resources preservation (Fricke et al., 2005).

In the present work, inventory data obtained in previous studies from different full-scale waste treatment plants operating in Catalonia (North-East of Spain, Mediterranean region) are used to estimate environmental impacts of the new MSW management scenario, mainly related to biowaste, that will be needed in Catalonia to fulfil the European Landfill Directive and the new recently approved Catalan waste management plan, PRECAT 2014-2020 (Agència de Residus de Catalunya, 2014). The main goal of this study is to compare different scenarios of organic waste management using the LCA methodology. These scenarios are based on real data collected from full scale waste treatment plants including uncertainties that are typically found in this type of plants such as fugitive emissions from anaerobic digesters, gaseous emissions from composting processes, etc. This region can serve as an example to other regions of Europe in similar situations, where the European recommendation must have to be applied in the mid-term future. 


\section{Methodology}

\subsection{Area studied}

The area under study corresponds to Catalonia, in the Mediterranean coast of Europe (North-East of Spain). Catalonia has an extension of approximately $32000 \mathrm{~km}^{2}$ and a population of 7,539,000 inhabitants (2011). In 2012, the municipal waste generation was of 3,731 Gg from which 1,457 Gg (39 \%) was source-selected (Agència de Residus de Catalunya, 2012). Previous and existing waste management plans in Catalonia clearly support the source-selection of all the fractions of municipal solid waste, in accordance with the European recommendations. Waste fractions considered in source-collection are: organic waste (OFMSW or biowaste), paper and cardboard, glass, plastics and light packaging, hazardous waste and refuse. Regarding the OFMSW, 384 Gg were collected in 2012 (all of them source-selected) plus 99 Gg of pruning waste (Agència de Residus de Catalunya, 2014). Pruning waste is used as bulking agent during composting in some treatment plants. A complete waste classification and sorting scheme can be found in the reports published by local administrations such as the Catalan Waste Agency (Agència de Residus de Catalunya, 2014).

Table 1 shows the current composition of MSW generated in Catalonia and Table 2 shows the amount of source-selected (SS-OFMSW) and non source-selected OFMSW (NSS-OFMSW) and its treatment/disposal destination.

\subsection{LCA General Methodology}

LCA is a methodology for the determination of environmental impacts associated to a product, process or service from cradle to grave, in other words, from production of the raw materials to ultimate disposal of waste. According to ISO 14040-14044 
(International Organization for Standardization, 2006), there are four main steps in a LCA study: the goal and scope definition, the inventory analysis, the impact assessment and the interpretation. In this study, the software SimaPro v. 7.1.8 (PRé Consultants, 2008) was used to evaluate the environmental impacts of all waste treatment technologies considered. Only the obligatory phases defined by the ISO 14040-14044 regulation for the impact assessment (International Organization for Standardization, 2006), namely classification and characterization, were performed as they avoid the subjectivity involved in impact evaluation (Martínez-Blanco et al., 2009). The impact assessment method used was CML 2001, which was based on the CML Leiden 2000 method developed by the Centre of Environmental Science of Leiden University (Guinée, 2002). The impact categories considered were: abiotic depletion (ADP), acidification (AP), eutrophication (EP), global warming (GWP), ozone layer depletion (OLDP) and photochemical oxidation (POP).

\subsection{Functional unit}

The key functions for all the technologies considered were the management of the OFMSW. The functional unit (FU) in LCA provides a reference to which the inputs and outputs of the inventory are related and allows the comparison among systems (International Organization for Standardization, 2006). In this study the functional unit (FU) selected was the management of one Mg of OFMSW.

\subsection{Description of the system}

Figure 1 shows the stages of the two systems considered in this LCA. Figure 1.a shows the current organic waste management model (Initial Scenario 1, ISc1), and Figure 1.b shows a proposed management model with the necessary modifications to fulfill the EU 
Landfill directive (Scenario LDSc1). The steps included in the scenarios are marked using a dashed line in Figure 1. These steps are: (i) waste collection and transport from collection points to treatment/disposal facilities; (ii) waste treatment and disposal of raw OFMSW including gaseous emissions, leachate treatment, energy and water consumption; and (iii) disposal of non-recovered OFMSW from mechanical pretreatment and biostabilized material including transportation from treatment facilities to final disposal installations (incineration and landfill).

Full description of the plants considered in this study can be found in previous works (Colón et al., 2012; Colón et al., 2010; Martínez-Blanco et al., 2010).

\subsubsection{General Assumptions}

General assumptions in this study for all the Scenarios are:

(i) It has been supposed that all the plants using the same treatment technology will produce the same impacts per Mg of OFMSW treated. Obviously, even with the same technology and presenting a very similar layout each plant has some particularities. However, the detailed study of all the individual plants in terms of environmental burdens calculation is beyond the scope of this study. The installations used were chosen as they were representative of each technology, including in the representativeness the fact that they are treating the same type of waste produced in the same region. It has been stated that the geographical variability of the waste characteristics is an important source of errors when inventory data are used from global databases (Fricke et al., 2005).

(ii) Amount of organic refuse: In order to estimate the amount of non-sourceselected OFMSW (NSS-OFMSW) that ends up in incinerators or sanitary 
landfills, the total amount of municipal solid waste was multiplied by its average organic fraction content (39 \%) (Agència de Residus de Catalunya, 2014). Organic refuse coming from source-selected and non-source-selected treatment plants also ends up in a final disposal destination. A previous study

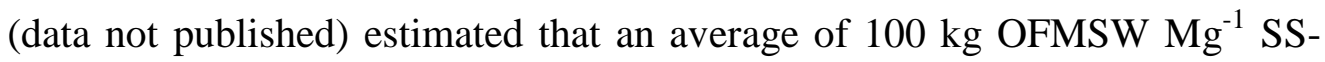
OFMSW and $250 \mathrm{~kg}$ OFMSW $\mathrm{Mg}^{-1}$ NSS-OFMSW were lost because of inefficient pretreatment processes (rotary screens, ballistic separators, etc.). These amounts of refuse are also considered in the LCA.

(iii) Transport: In this study, both urban transport collection and intercity transport to the plant were considered (Iriarte et al., 2009). A total value of $30.6 \mathrm{tkm} \mathrm{t}^{-1}$ OFMSW for collection and transport of waste to waste treatment facilities was used. This data was reported by Martinez-Blanco et al. (2010) assuming a 21 ton MAL lorry specifically designed for waste collection (Ecoinvent 2) and an average distance from the collection points to the treatment facilities (composting and MBT facilities) close to $10 \mathrm{~km}$. The return trips made by the trucks were also included in the calculation. Thus, this average value has been used for all the OFMSW collected in Catalonia as no specific data was found for other regions. Although there are not reliable data on average distances from collection areas and its final disposal facilities (incineration and sanitary landfill), taking into account the distance from main urban areas and final disposal installations where the OFMSW is sent, an average distance from collection areas of $5 \mathrm{~km}$ and $20 \mathrm{~km}$ are assumed for incineration facilities and sanitary landfills respectively (the urban transport collection distance is considered the same as in composting and MBT facilities), thus a value of 
20.6 and $50.6 \mathrm{tkm} \mathrm{t}^{-1}$ OFMSW has been used for incineration and sanitary landfills respectively. No transport was considered for home composting.

(iv) Greenhouse gases emissions: Regarding $\mathrm{CO}_{2}$ emissions from the biological treatment process, they have not been considered in impacts calculation due to the general consensus (Intergovernmental Panel on Climate Change, IPCC) that $\mathrm{CO}_{2}$ from this type of treatments is of biogenic origin and it does not contribute to global impacts (IPCC, 2006). Biogas emissions in anaerobic digestion plants were measured only on biofilter surfaces, the fugitive emissions from other sources (pipes, pressure release from the reactor, flared biogas) have been considered close to zero following the IPCC recommendations as no experimental measurement was possible (IPCC, 2006).

(v) The impacts derived from plant and machinery construction were not included because in a previous study (Martinez-Blanco et al., 2010) it was found that their overall contribution in all the impact categories was less than $2.5 \%$.

Particular assumptions for each Scenario are detailed below.

\subsubsection{Initial Scenario 1}

This Scenario reflects the situation in 2012. Table 3 shows the number of facilities treating municipal organic waste in operation and the amount of waste treated at each type of facility during that year. The amount of SS-OFMSW treated at each installation has been directly obtained from data provided by the Catalan Waste Agency (Agència de Residus de Catalunya, 2014). In the SS-OFMSW input stream, $15 \%$ of impurities were measured as average. Regarding home composting, no impurities $(0 \%)$ were considered. 
The existing installations in 2012 and the geographic distribution are presented in Figure 2. Two main areas can be differentiated in Catalonia, the first one is the metropolitan area of Barcelona which includes Barcelona city and its nearby cities; this area is characterized by a high population density and a high degree of industrialization (3.500.000 inhabitants). The second one is the remaining part of Catalonia that is characterized by low-density population and in terms of waste management, it still relies strongly on landfilling.

\subsubsection{Scenario LDSc1}

This hypothetical scenario treats the same amount of organic waste as ISc1. This scenario would permit to fulfill the requirements of the European Union Landfill Directive (Council of European Union, 1999) and the recently approved Catalonia waste management plan (PRECAT 2014-2020). This scenario is based on two main premises: (i) $60 \%$ of municipal organic waste must be source-selected and valorized and (ii) $100 \%$ of mixed MSW must be treated at MSW-MBT facilities. Therefore, the final disposal (incineration and sanitary landfill) of untreated MSW is not allowed.

The metropolitan area of Barcelona has a total installed treatment capacity of $346.5 \mathrm{Gg}$ and 1,310 Gg of SS-OFMSW and MSW respectively. The current installed capacity is enough to treat all municipal waste generated in this area and the construction of new installations is not expected. Moreover, there is an extra AD treatment capacity originally designed to treat NSS-OFMSW that is currently out of use and could potentially be used as a SS-OFMSW treatment. As a result, there is a total installed AD treatment capacity close to $404 \mathrm{Gg}$. Assuming a $60 \%$ source selection of OFMSW, a total amount of 400

Gg will be generated and potentially could be treated by means of AD. The remaining 
NSS-OFMSW waste generated in the metropolitan area of Barcelona will be treated at the currently in operation MSW-CT plants.

On the contrary, the installed treatment capacity of both SS-OFMSW and MSW in the remaining part of Catalonia is not enough to treat the total amount of waste generated and in consequence, several installations must be designed and constructed. The total installed SS-OFMSW treatment capacity is close to $137 \mathrm{Gg}$, and an extra treatment capacity of 136 Gg will be necessary to accomplish the proposed regulation. Regarding MSW treatment plants only a treatment capacity of $444 \mathrm{Gg}$ is currently installed, and the construction of new facilities will be necessary to be able to treat the remaining MSW.

Assuming the abovementioned conditions, the following considerations are selected for LDSc1 scenario:

(i) All the SS-OFMSW generated in the metropolitan area of Barcelona will be treated by means of $\mathrm{AD}$.

(ii) Some CT facilities are currently planned and/or being built, these new facilities are included in this scenario.

(iii) As stated above $\mathrm{AD}$ is the more environmental friendly technology, thus the new installations (not yet planned) will be designed using this technology.

(iv) Home composting treatment capacity will be increased from $5 \mathrm{Gg}$ in ISc1 up to $25 \mathrm{Gg}$ (50.000 inhabitant equivalent).

(v) AWC and TWC plants will be remodeled to include gas treatment installations (biofilters) to minimize the $\mathrm{NH}_{3}$ and VOC emissions (AWB facilities). The efficiency of these units will be based on experimental data. 
(vi) All NSS-OFMSW will be treated at MSW-CT plants.

\subsection{Life cycle inventory: Quality and origin of the data}

Real data on SS-OFMSW treatment facilities was obtained in previous works (Colon et al., 2012; Martinez-Blanco et al., 2010). In these works, a representative treatment facility of each type (AD, CT, AWC, TWC) was studied in detail to determine the environmental burdens associated to plant operation. The plants studied (5 treatment plants) were selected after a deep discussion with the Catalan Waste Agency for their representativeness, as a detailed study of all plants in operation was out of the possibilities of the work. Inventory data on energy and water consumption, waste treated, impurities separation and compost produced (as well as biogas in the case of the anaerobic digestion installation) was obtained from plant managers. In addition, an accurate gaseous emissions sampling was undertaken in order to quantify the emissions of ammonia, volatile organic compounds (VOC), methane and nitrous oxide (the methodology can be consulted in Colón et al. (2012) and Cadena et al. (2009)). Home composting was also studied as a treatment alternative for the OFMSW in low-density population areas (Colón et al., 2010; Martínez Blanco et al., 2010). Table 4 summarizes the inventory data obtained in the above-mentioned previous studies (Colón et al., 2012; Martinez et al., 2010). These data has been used as the basis to perform the calculations presented in this paper. Nowadays, in Catalonia aerated and turned windrows composting plants are not provided with gaseous emissions treatment equipment. Taking into consideration the impacts that can be derived from ammonia and VOC emissions, a new type of treatment plant (AWB) has been added to Table 4. AWB represents a theoretical configuration where composting occurs in aerated and turned windrows placed on a closed installation with gaseous emissions treatment using biofilters (as stated above, no 
facilities with these characteristics are found in the studied area). Values on real biofilter efficiencies in contaminant removal were considered to determine reduced impacts (Amlinger et al., 2008; Colón et al., 2009) and are presented in Table 4. Energy consumption associated to biofilter operation was considered as an additional impact (also reported in Table 4) and obtained from Cadena (2009).

Regarding the treated NSS-OFMSW, most mechanical biological treatment plants (MBT) rely on composting tunnels plus a curing phase and to a lesser extent anaerobic digestion plus curing phase. The environmental burdens of these operations are related to energy consumption (tunnel and building ventilation, fuel consumption, etc.) and gases emissions/treatment. All these phases are considered in the LCA of source-selected composting tunnel (CT) and anaerobic digestion plants (AD) including also the energy recovery. The main difference is the extra energy needed at the pretreatment stage, but the allocation of this extra energy consumption should be accounted with the material recovery stage (packaging, metal, paper and cardboard). Therefore, in this work the environmental impact of MSW-MBT (MSW-AD \& MSW-CT) plants is considered the same as the environmental impact related to SS-OFMSW treatment (CT or AD facilities).

Table 5 summarizes the values calculated for the different impact potentials for each of the studied plants related to the treatment of $1 \mathrm{Mg}$ of OFMSW. AD facilities have the best overall performance in terms of environmental impacts in all categories.

Finally, in order to calculate the impact potentials of NSS-OFMSW and OFMSW refuse disposed at incineration facilities or sanitary landfills, data coming from ELCD database specifically compiled for the Mediterranean region were used. The modeled landfill includes energy recovery (Distribution of landfill gas: $22 \%$ flare, $28 \%$ used, $50 \%$ 
emissions) and leachate treatment. The modeled incineration also includes energy recovery and ash disposal to sanitary landfill.

\subsection{Sensitivity analysis}

Environmental impacts for several hypothetical scenarios in ISc1 and LDSc1 obtained by modifying relevant considerations were assessed to perform a sensitivity test for the following issues:

(i) Transport: ISc2 and LDSc2 do not include transport while in ISc3 transport distances are reduced by a half.

(ii) Methane fugitive emissions: ISc4, ISc5, LDSc5 and LDSc6 consider different amounts of methane uncontrolled emissions. As stated above, methane emissions were measured only on biofilter surfaces. However, some studies (Møller et al., 2009) showed fugitive emissions ranging from 0 to $10 \%$ of the total methane produced, for this reason, a sensitivity analysis including a percentage of 5 and $10 \%$ fugitive emissions plus the combustion of biogas has also been included. Since $98.8 \mathrm{~m}^{3}$ biogas $\mathrm{Mg}^{-1}$ OFMSW were produced during the studied anaerobic digestion process, and assuming average methane content of $65 \%$, methane fugitive emissions of 2.3 and $4.6 \mathrm{~kg} \mathrm{CH} \mathrm{Mg}^{-1}$ OFMSW for 5 and $10 \%$ fugitive emissions were considered respectively in the sensitivity analysis. During combustion in biogas engines, methane is converted to energy and $\mathrm{CO}_{2}$, but as the combustion process is not $100 \%$ efficient, some methane is left unburned and in this way contributes to the GWP, $0.8 \mathrm{~kg} \mathrm{CH}_{4} \mathrm{Mg}^{.1}$ OFMSW (Møller et al., 2009) were considered. Thus, a total amount of 3.1 and $5.4 \mathrm{~kg} \mathrm{CH}_{4} \mathrm{Mg}^{-1}$ OFMSW can be considered when fugitive emissions are taken into account (5 and 10\% sensitivity analysis 
respectively). The fugitive emissions accounted for 57.5 and $115 \mathrm{~kg} \mathrm{CO}_{2}$ eq. $\mathrm{Mg}^{-1}$ OFMSW (5 and $10 \%$ sensitivity analysis respectively) and the combustion of biogas accounted for $20 \mathrm{~kg} \mathrm{CO}_{2}$ eq. $\mathrm{Mg}^{-1}$ OFMSW (for both 5 and $10 \%$ sensitivity analysis). To our knowledge, this is the first study where fugitive emissions of methane are considered in LCA.

(iii) Biogas collection in landfills: In ISc6 and LDSc7 a collection efficiency of $17 \%$ is considered which correspond to the actual biogas collection estimation in Catalan landfills. LDSc8 considers a collection efficiency of $60 \%$ as predicted in PRECAT 2014-2020 (Agència de Residus de Catalunya, 2014).

(iv) Use of compost and biostabilized material: ISc7 and LDSc9 consider the use of compost as an organic amendment. ISc8 and LDSc10 consider the use both compost and biostabilized material. Biostabilized material results from the treatment of NSS-OFMSW.

(v) Treatment technologies: In LDSc3 supposes that the new SS-OFMSW facilities that will be needed will be designed using composting (CT) instead of AD. In LDSc4 all the extra SS-OFMSW will be treated in composting tunnels $(\mathrm{CT})$ installations while $\mathrm{AD}$ will remain treating the same amount of waste as in ISc1 (which means that the extra AD capacity currently installed and out of use will remain unused).

\section{Results and discussion}

\subsection{Initial Scenario 1}

In addition to the number of installations in operation for each treatment technology and the total waste treated, Table 3 also present the impact potential values calculated on a 
yearly basis using data from Table 5 and data from Ecoinvent (transport) and ELCD (sanitary landfill and incineration) dabatases.

As seen in Table 3 and Figure 3.a, the OFMSW landfilled without any treatment (28\%) is the main responsible for the GWP (47.4\%) and EUP (55.2\%), these impacts are mainly related to air emissions (methane and ammonia) and water emissions (phosphorus and nitrogen compounds). If the environmental impacts of landfilled refuse are also included, the total GWP and EUP percentages increase up to 60.8 and 85.6 respectively. The NSSOFMSW treated at MBT facilities (36\%) has an environmental impact ranging from 2.5 to $35 \%$ in all categories, its main contributions found in AP $(26.5 \%)$ and POP $(35.6 \%)$. On the contrary, incineration $(8 \%)$ has low impact $(<5 \%)$ in all categories.

The SS-OFMSW (27\%) is the main responsible for the AP (35.5\%) and POP (49\%); a closer analysis focusing on the type of source-selected treatment installations shows that treatment plants without gaseous emissions treatment (AWC and TWC) are the main responsible for AP (76.5\%), POP (52.5\%) and EUP (77\%) although they are only treating $14 \%$ of the total amount of SS-OFMSW. These data demonstrate the contribution of the gaseous treatment equipment to the reduction of the impact of the OFMSW treatment plants in some of the impact potentials. However, the energy required by this equipment derives in higher contributions to GWP, ADP and ODP, as occurs in the case of CT plants. Biogas recovery in $\mathrm{AD}$ plants and the existence of gaseous emissions treatment result in relatively lower impact potential values.

Finally transportation has its main impacts in ADP (40.3\%), OLDP (66.5\%) and AP (20\%). Because of the amount treated and the longer distance to sanitary landfills from the collection point, the transportation of the NSS-OFMSW landfilled without any treatment is the responsible of $40 \%$ of the total transport impacts. 


\subsubsection{ISc sensitivity analysis}

As the results obtained correspond to a quite particular situation, environmental impacts for several hypothetical scenarios obtained by modifying relevant assumptions of the OFMSW management model were assessed and compared with the initial scenario studied (ISc1) to perform the sensitivity analysis of the results. As stated in the Methodology section, four new issues were studied: (i) the distance between the treatment/disposal installations and the collection point, (ii) the methane fugitive emissions in AD and MSW-AD plants, (iii) the efficiency of biogas collection in sanitary landfills and (iv) the use of compost as an organic amendment. Results are shown in Table 6.

A first scenario (ISc2) without considering the transport is proposed to highlight only the differences among the treatment technologies. Figure 3.b shows the environmental impact of each treatment technology. Regarding ADP and OLDP, the two impact categories in which transport was the main responsible in ISc1, landfilling and NSSOFMSW treatment plants are in ISc2 the main contributors with an overall percentage ranging from 20 to $45 \%$.

As the emplacement of treatment facilities and final disposal installations may change as a function of the local distribution and restrictions of this kind of facilities, distances from collection points have been changed. Distances of $5 \mathrm{~km}$ and $10 \mathrm{~km}$ between the collection point and the SS-OFMSW treatment facility and the sanitary landfill have been respectively considered (ISc3) (half the distance considered in ISc1). Impacts in scenario ISc3 were significantly lower for ADP (14\%) and OLDP (23\%) impact categories, whereas no significant reductions $(<7 \%)$ were observed for the rest of categories. 
An important factor usually omitted is the methane fugitive emissions produced in AD and MSW-AD installations. Scenarios ISc4 and ISc5 include methane fugitive emissions of 5 and $10 \%$ respectively in the inventory. Methane contributes mainly in GWP and in a lesser extent in POP. As can be seen in Table 6, taking into account the whole management system an increase of 4 and $9 \%$ of GWP is reported when fugitive emissions are considered. In terms of POP the increment is negligible $(<2 \%)$. When considering $\mathrm{AD}$ or MSW-AD installations, these fugitive emissions have a huge impact on GWP increasing up to $400 \%$ (10\% fugitive emissions) its initial value considered in ISc1. These data must be taken into account when planning the future LDSc scenario, as AD has been pointed as the most suitable treatment technology, but fugitive emissions close to $10 \%$ will eventually lead to an important increment in GWP if AD is widely spread.

Landfill gas collection systems are assessed in ISc6. Although in ISc1 the biogas recovered is $50 \%$ ( $22 \%$ flared $+28 \%$ energy recovery), several studies pointed out that the current biogas recovery in Catalonia could be as low as 17\% (Sostenipra, 2013); therefore a new scenario is modeled taking into account this amount of biogas recovery. In this situation, each ton of landfilled organic material releases to the atmosphere $786 \mathrm{~kg}$ $\mathrm{CO}_{2}$ eq, and a significant increase in GWP (36\%) is observed.

Finally, the use of compost and also the use of biostabilized material as organic amendment are assessed in ISc7 and ISc8 in terms of GWP contribution. An avoided impact of $88 \mathrm{~kg} \mathrm{CO}$ eq/t compost arises (Sostenipra, 2013) which implies a GWP reduction ranging from 2 to $5 \%$. Although not included in this study, the agricultural use of compost also have many other advantages as for example the nutrient supply, the weed and disease suppression, the improvement of soil workability, the increase of the water holding and cation-exchange capacity and the prevention of soil erosion among others (Favoino and Hogg, 2008; Martinez-Blanco et al., 2013). The current legislation does not 
recommend the use of biostabilized material as organic amendment, in consequence, the vast majority of biostabilized material is used for the recovery of sanitary landfills and in a lesser extent for quarry restoration.

\subsection{Scenario LDSc1}

For each treatment technology, Table 7 presents the total Gg treated at each installation and the impact potential values calculated on a yearly basis using data from Table 5 and data from Ecoinvent (transport) and ELCD (sanitary landfill and incineration) databases.

Although fresh NSS-OFMSW is not landfilled without treatment, the refuse coming from both SS-OFMSW and NSS-OFMSW treatment facilities that ends up to sanitary landfill still has a significant impact in categories such as GWP, ADP and mainly EUP.

Landfill methane emissions still represent a total impact close to $28 \%$ (Fig. 4.a) of the overall GWP and if the transport is not taken into account (Fig 4.b) this percentage increases up to $37 \%$. The same situation occurs regarding EUP, although the landfilled OFMSW is strongly minimized, it still is the main contributor to EUP with a total contribution close to $75 \%$. These data highlight the importance of improving both source selection and the efficiency of the pretreatment processes to minimize the lost of fresh organic matter during pretreatment processes.

\subsubsection{LDSc sensitivity analysis}

Environmental impacts for several hypothetical scenarios obtained by modifying relevant assumptions of the OFMSW management model were assessed and compared with the initial scenario studied (LDSc1) to perform the sensitivity analysis of the results. Five 
issues were assessed (see Methodology section): (i) transport is not considered, (ii) methane fugitive emissions in $\mathrm{AD}$ plants, (iii) the efficiency of biogas collection in sanitary landfills, (iv) the use of compost as an organic amendment and (v) the use of CT technology instead of AD. Results are shown in Table 8.

A first scenario (LDSc2) without considering the transport is proposed in order to highlight only the differences among the treatment technologies. Figure 4.b shows the environmental impact of each treatment technology. Regarding ADP and OLDP, the two impact categories in which transport was the main responsible in LDSc1, NSS-OFMSW treatment plants (MSW-CT) are in LDSc2 the responsible of more than $60 \%$ of the overall impact.

Due to higher capital costs and higher operation complexity, it is probable that AD will not be the main treatment technology applied to new facilities. Therefore two new scenarios are proposed (LDSc3 and LDSc4). LDSc3 scenario uses all the current AD installed capacity (current facilities in operation and out of use reactors designed for treating NSS-OFMSW) but considers that all new installations will be using CT technologies. This scenario shows that the change in all impact potentials is less than $5 \%$. On the other hand LDSc4, maintains the same amount of waste currently treated by AD and assumes that the new SS-OFMSW will be treated by means of CT facilities (out of use $\mathrm{AD}$ reactors will not be used). In that case, all the impact potentials related to energy recovery/consumption (GWP, ADP, AP and OLDP) present an increment ranging from 8 to $28 \%$.

AD treatment capacity in LDSc1 scenario is more than two times higher than in ISc1, so the fugitive emissions control becomes of upmost importance. LDSc5 and LDSc6 include 
in the inventory fugitive emissions of 5 and $10 \%$ respectively. In the worst-case scenario the GWP could increase up to $31 \%$.

Landfill gas collection systems are assessed in LDSc7 and LDSc8. LDSc7 as in the case of ISc6 uses only a 17\% of landfill gas recovery. On the contrary, the collection efficiency is increased up to $60 \%$ in LDSc8, this percentage of biogas recovery is proposed as a goal by the Catalan Waste Agency in PRECAT 2014-2020 (Agència de Residus de Catalunya, 2014). As only organic refuse are landfilled and the biogas recovery in LDSc1 is 50\% (flared + used), a small difference is shown in GWP of LDSc8. On the contrary an increase of $17 \%$ in GWP is shown when biogas collection is decreases until $17 \%$.

Finally, the use of compost and also the use of biostabilized material as organic amendment are assessed in LDSc9 and LDSc10 in terms of GWP contribution. Due to the increase in source selection and also the amount of MSW treated at MBT plants, the production of compost and biostabilized material rises from 83 to 183 and from 110 to $121 \mathrm{Gg}$ respectively. Reductions from 7 to $12 \%$ are expected in GWP when these materials are used as an organic amendment.

\subsection{Comparison of both scenarios}

Figure 5 shows the comparison of both waste management scenarios, ISc1 and LDSc1. The new LDSc1 scenario decreases the environmental impact in 5 out of 6 impact categories; only POP shows a higher impact (23\%), this increment is mainly due to the higher VOC emissions during composting processes compared with VOC landfill emissions (ELCD database). 
GWP shows a decrease of $36 \%$ mainly because of the absence of landfilled NSSOFMSW. It is important to remark that probably the current landfill biogas capture efficiency is close to $17 \%$ and the goal is to achieve an efficiency of $60 \%$, therefore a comparison of scenarios ISc6 and LDSc8 should be performed. In this situation a GWP decrease close to $55 \%$ is achieved. If the use of compost coming from SS-OFMSW as an organic amendment is also taken into account, a maximum decrease close to $58 \%$ could be expected. The Catalan Office for Climate Change (Oficina Catalana del Canvi Climàtic, 2014) reported a total estimated GWP close to 46,000 $\mathrm{Gg} \mathrm{CO}_{2}$ eq. year ${ }^{-1}$ (2012), data presented in this study shows that in the best and worst case scenario, LDSc8 and ISc6 respectively, the total contribution of organic waste treatment to GWP only represents between 0.47 and $1.05 \%$ of the overall impact.

Abiotic depletion shows a decrease of $16 \%$, this impact reduction can be attributed to two different factors. The first one is related to the increase of the amount of organic waste treated by $\mathrm{AD}$ facilities, Table 5 shows that because of the energy recovery in $\mathrm{AD}$ plants, there is an avoided impact in terms of ADP. The second factor is related to the decrease of intercity transport, treatment facilities are located at an average distance of 10 $\mathrm{km}$ while sanitary landfills are at an average distance of $20 \mathrm{~km}$.

A decrease of $17 \%$ is achieved regarding AP. The main contributors to this impact category are the biological treatment plants, especially the ones without gaseous emissions treatment, with ammonia and electricity consumption as the main contributors to this category. Consequently, the new AWB configuration proposed in this work as well as the increase of the amount of organic waste treated by AD facilities (energy recovery) are the responsible of the decrease in $\mathrm{AP}$ value. 
EUP has the highest impact reduction (49\%). Again, this reduction can be attributed to two factors. Nitrogen and phosphorous compounds released from landfills are the main responsible of this impact; therefore the absence of landfilled NSS-OFMSW avoids a substantial part of this impact. Moreover, ammonia emissions from treatment plants, especially the ones without gas treatment, were also responsible for EUP, the new AWB proposed plants reduce up to $70 \%$ the EUP compared with the TWC and AWC composting plants.

Finally, a $9 \%$ reduction is only observed for OLDP. This decrease can be almost entirely attributed to the decrease of the transportation of NSS-OFMSW to landfills.

\section{Conclusions and remarks}

- The main conclusion of this study is that the environmental performance of the different OFMSW treatment technologies should be included as a decision criterion in waste management planning.

- The new LDSc1 scenario decreases the environmental impact in 5 out of 6 impact categories (GWP, ADP, AP, EUP and OLDP) and only POP shows a higher impact.

- Sensitivity analysis shows that an improvement of landfill gas collection is of utmost importance in order to decrease the GWP. Also a detailed study regarding fugitive methane emissions in $\mathrm{AD}$ installations is necessary, as $\mathrm{AD}$ has been pointed out as the most suitable technology from an environmental point of view, but in the case studied fugitive methane emissions could increase the GWP up to $31 \%$ if this technology is widely used in new treatment facilities.

- The use of anaerobic digestion (LDSc1) instead of composting tunnels (LDSc4) shows better performance (ranging from 8 to $28 \%$ ) in GWP, ADP, AP and OLDP 
impact categories. However when fugitive emissions are included (LDSc5 and LDSc6), GWP increases up to $30 \%$. Hence, in this situation the use of composting tunnels could be a more environmental friendly technology regarding GWP impact category.

- It should also be highlighted that there are economical and social constraints regarding waste management planning that have not been considered in this study. The cost of the different treatment options, the importance of the waste collection system and the source selection process as well as social acceptance required for home composting implementation are extremely important factors.

\section{Acknowledgements}

This study was financially supported by the Spanish Ministerio de Economía y Competitividad (Project CTM2012-33663) with FEDER funding and the Agència de Residus de Catalunya. Erasmo Cadena and Joan Colón thank Universidad Autónoma de Tamaulipas and Universitat Autònoma de Barcelona, respectively, for the award of a predoctoral fellowship.

\section{References}

Agència de Residus de Catalunya (Catalan Waste Agency): Statistics of Waste Generation in Catalonia 2012.

http://www20.gencat.cat/docs/arc/Home/Consultes\%20i\%20tr\%C3\%A0mits\%20\%20nou/Estadistiques/Estadistiques\%20de\%20residus\%20municipals/recollida_selec tiva_2012.pdf. Accessed July 2014 
Agència de Residus de Catalunya (Catalan Waste Agency): PRECAT 2014-2020.

http://participacioarc.cat/docs/PRECAT20/PRECAT20.pdf. Accessed 3 July 2014

Agència de Residus de Catalunya (Catalan Waste Agency): Summary of the Municipal

Waste Management Program

http://www20.gencat.cat/docs/arc/Home/Ambits\%20dactuacio/Planificacio/progremic _resum.pdf. Accessed July 2014.

Amlinger F, Peyr S, Cuhls C. 2008. Greenhouse gas emissions from composting and mechanical biological treatment. Waste Manage. Res. 26:47-60.

Arena U, Mastellone ML, Perugini F. 2003. The environmental performance of alternative solid waste management options: a life cycle assessment study. Chem. Eng. J. 96: 207-222.

Banar M, Cokaygil Z, Ozkan A. 2009. Life cycle assessment of solid waste management options for Eskisehir, Turkey. Waste Manage. 29: 54-62.

Björklund A, Finnveden G. 2007. Life cycle assessment of a national policy proposal The case of a Swedish waste incineration tax. Waste Manage. 27: 1046-1058.

Bovea MD, Ibáñez-Forés V, Gallardo A, Colomer-Mendoza FJ. 2010. Environmental assessment of alternative municipal solid waste management strategies. A Spanish case study. Waste Manage. 30: 2383-2395.

Cadena E, Colón J, Sánchez A, Font X, Artola A. 2009. A methodology to determine gaseous emissions in a composting plant. Waste Manage. 29:2799-2807.

Cadena E. 2009. Environmental impact analysis at full-scale OFMSW biological treatment plants. Focus on gaseous emissions. PhD Thesis, Universitat Autònoma de Barcelona, Bellaterra, Spain. http://ddd.uab.cat/pub/tesis/2009/tdx-1027110003459/ec1de1.pdf. Accessed July 2014. 
Cleary J. 2009. Life cycle assessment of municipal solid waste management systems: A comparative analysis of selected peer-reviewed literature. Environ. Int. 35: 12561266.

Clift R, Doig A, Finnveden G. 2000. The application of Life Cycle Assessment to integrated solid waste management. Part 1 - Methodology. Trans IChemE. 78B: 279287.

Colón J, Martínez-Blanco J, Gabarrell X, Rieradevall J, Font X, Artola A, Sánchez A. 2009. Performance of an industrial biofilter from a composting plant in the removal of ammonia and VOCs after material replacement. J. Chem. Technol. Biotechnol. 84:1111-1117.

Colón J, Martínez-Blanco J, Gabarrell X, Artola A, Sánchez A, Rieradevall J, Font X. 2010. Environmental assessment of home composting. Resour. Conserv. Recy. 54:893-904.

Colón J, Cadena E, Pognani M, Barrena R, Sánchez A, Font X, Artola A. 2012. Determination of the energy and environmental burdens associated with the biological treatment of source-separated Municipal Solid Wastes. Energy Environ. Sci. 5:5731-5741.

Council of the European Union. 1999. Directive 1999/31/EC, on the Landfill of Waste. Official Journal of the European Communities, L 182/1, 16.07.1999.

European Commission. 2008. Green Paper on the Management of Bio-waste in the European Union 2008. http://eurlex.europa.eu/LexUriServ/LexUriServ.do?uri=COM:2008:0811:FIN:EN:PDF. Accessed July 2014. 
European Parliament and Council. 2008. Directive 2008/1/EC of 15 January 2008 concerning integrated pollution prevention and control. Official Journal of the European Union, L 24/8, 29.01.2008.

Favoino F, Hogg D. 2008. The potential role of compost in reducing greenhouse gases. Waste Manage Res. 26:61-69.

Fernández-Nava Y, del Río J, Rodríguez-Iglesias J, Castrillón L, Marañón E. (2014). Life cycle assessment of different municipal solid waste management options: a case study of Asturias (Spain). J. Clean. Prod. 81: 178-189.

Finnveden G, Hauschild MZ, Ekvall T, Guinée J, Heijungs E, Hellweg S, Koehler A, Pennington D, Suh S. 2009. Recent developments in Life Cycle Assessment. J Environ Manage. 91: 1-21.

Fricke K, Santen H, Wallmann R. 2005. Comparison of selected aerobic and anaerobic procedures for MSW treatment. Waste Manage. 25:799-810.

Guinée JB. 2002. Life Cycle Assessment, an Operational Guide to the ISO Standars. Parts 1, 2 and 3. Ministry of Housing. Spatial Planning and Environment (VROM) and Centre of Environmental Science (CML). Den Haag and Leiden, The Netherlands.

Intergovernmental Panel on Climate Change, IPCC. 2006. IPCC Guidelines for National Greenhouse Gas Inventories, http://www.ipccnggip.iges.or.jp/public/2006gl/index.htm. Accessed July 2014. Interrnational Organisation for Standardisation. 2006. ISO 14040-14044. Environmental Management, Life Cycle Assessment. International Standard, Geneva, Switzerland. Iriarte A, Gabarrell X, Rieradevall J. 2009. LCA of selective waste collection systems in dense urban areas. Waste Manage. 29:903-914. 
Laurent A, Bakas I, Clavreul J, Bernstad A, Niero M, Gentil E, Hauschild MZ,

Christensen TH. 2014. Review of LCA studies of solid waste management systems Part I: Lessons learned and perspectives. Waste Manage. 34: 573-588.

Martínez-Blanco J, Lazcano C, Christensen TH, Muñoz P, Rieradevall J, Møller J, Antón A, Boldrin A. 2013. Compost benefits for agriculture evaluated by life cycle assessment. A review. Agron. Sustain. Dev. 33:721-732

Martínez-Blanco J, Colón J, Gabarrell X, Font X, Sánchez A, Artola A, Rieradevall J. 2010. The use of life cycle assessment for the comparison of biowaste composting at home and full scale. Waste Manage. 30:983-994.

Martínez-Blanco J, Muñoz P, Antón A, Rieradevall J. 2009. Life cycle assessment of the use of compost from municipal organic waste for fertilization of tomato crops.

Resour. Conserv. Recy. 53:340-351.

Møller J, Boldrin A and Christensen TH. 2009. Anaerobic digestion and digestate use: accounting of greenhouse gases and global warming contribution. Waste Manage. Res. 27:813-824.

Oficina Catalana del Canvi Climàtic (Catalan Climate Change office). 2014. Catalunya i els objectius de reducció d'emissions de gasos amb efecte d'hivernacle. http://www20.gencat.cat/docs/canviclimatic/Home/Campanyes\%20i\%20comunicacio /Publicacions/Publicacions\%20de\%201Oficina\%20Catalana\%20de1\%20Canvi\%20Cli matic/Quart\%20informe\%20de\%20progres\%20a\%20Catalunya/Quart\%20Informe\%2 0de\%20Progres_Febrer2014.pdf. Accessed July 2014.

Thomas B, McDougall F. 2005. International expert group on life cycle assessment for integrated waste management. J. Clean. Prod. 13: 321-326. 
Table 1. Municipal solid waste (in Gg) generated in Catalonia during year 2012 (Agència de Residus de Catalunya, 2014).

\begin{tabular}{lr}
\hline \multicolumn{1}{c}{ Catalonia municipal waste } \\
\hline Total MSW & $\mathbf{3 , 7 3 1}$ \\
Total mixed municipal solid waste & $\mathbf{2 , 2 7 4}$ \\
Total source selected municipal solid waste & $\mathbf{1 , 4 5 7}$ \\
Biodegradable solid waste & 488 \\
Pruning & 99 \\
OFMSW (15\% improper material) & 384 \\
OFMSW (improper free) & 326 \\
Home composting & 5 \\
Paper and cardboard & 318 \\
Glass & 169 \\
Packaging & 135 \\
Others (bulky material, oil, tires, textile, \\
batteries, inert material, hazardous \\
materials, etc.) & 347 \\
\hline
\end{tabular}


Table 2. Organic waste generated and treated (in Gg) in Catalonia during year 2012 (Agència de Residus de Catalunya, 2014).

\begin{tabular}{lr}
\hline \multicolumn{2}{c}{ Catalonia municipal organic waste } \\
\hline Biodegradable solid waste generation & 1,317 \\
Pruning & 99 \\
Total OFMSW generated & 1,218 \\
Total source selected OFMSW treated & 326 \\
Home composting & 5 \\
Total OFMSW not source selected & 887 \\
Landfilled without treatment* & 344 \\
Incineration* & 103 \\
Treated in MBT plants* & 440 \\
\hline
\end{tabular}

*39 \% of mixed MSW corresponded to OFMSW (Agència de Residus de Catalunya, 2014) 
Table 3. Scenario ISc1: Amount of waste treated, number of waste treatment and disposal installations and total and partial impact results.

\begin{tabular}{|c|c|c|c|c|c|c|c|c|}
\hline & $\begin{array}{l}\text { Number of } \\
\text { installations }\end{array}$ & $\begin{array}{c}\text { Treated } \\
\text { OFMSW } \\
\left(\mathrm{Gg} \mathrm{y}^{-1}\right) \\
\end{array}$ & $\begin{array}{c}\text { GWP } \\
\left(\mathrm{t} \mathrm{CO}_{2} \text { eq y}^{-1}\right) \\
\end{array}$ & 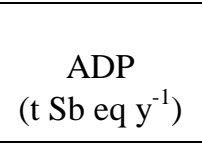 & $\begin{array}{c}\mathrm{AP} \\
\left(\mathrm{t} \mathrm{SO}_{2} \text { eq y }^{-1}\right) \\
\end{array}$ & $\begin{array}{c}\text { EUP } \\
\left(\mathrm{t} \mathrm{PO}_{4}^{3-} \text { eq } \mathrm{y}^{-1}\right) \\
\end{array}$ & $\begin{array}{c}\text { OLDP } \\
\left(\mathrm{t} \mathrm{CFC-11} \mathrm{eq} \mathrm{y}{ }^{-1}\right) \\
\end{array}$ & $\begin{array}{c}\text { POP } \\
\left(\mathrm{t}_{2} \mathrm{H}_{4} \mathrm{eq} \mathrm{y}^{-1}\right) \\
\end{array}$ \\
\hline \multicolumn{9}{|l|}{ Source-selected OFMSW } \\
\hline Anaerobic Digestion (AD) & 5 & 196 & 8,859 & -31.4 & 31.4 & 13.7 & $-5.23 \mathrm{E}-05$ & 70.6 \\
\hline In-vessel composting $(\mathrm{CT})$ & 7 & 85 & 8,934 & 51.2 & 76.3 & 6.2 & $4.65 \mathrm{E}-04$ & 30.0 \\
\hline Aerated windrows composting (AWC) & 3 & 25 & 3,075 & 10.8 & 93.8 & 18.0 & $1.13 \mathrm{E}-04$ & 64.8 \\
\hline Turned windrows composting (TWC) & 7 & 20 & 3,920 & 2.8 & 280.0 & 60.6 & 4.74E-05 & 47.6 \\
\hline Home composting (HC) & 20,000 & 5 & 1,045 & 0.2 & 7.0 & 1.5 & $1.53 \mathrm{E}-06$ & 1.2 \\
\hline Collection and transport & & 326 & 13,333 & 86.7 & 59.7 & 11.9 & $2.00 \mathrm{E}-03$ & 2.3 \\
\hline \multicolumn{9}{|l|}{ Non Source-selected OFMSW (from mixed MSW) } \\
\hline Anaerobic Digestion (MSW-AD) & 1 & 41 & 1,853 & -6.6 & 6.6 & 2.9 & $-1.09 \mathrm{E}-05$ & 14.8 \\
\hline In-vessel composting (MSW-CT) & 10 & 399 & 41,939 & 240.6 & 358.1 & 29.2 & $2.18 \mathrm{E}-03$ & 140.8 \\
\hline Collection and transport & & 440 & 17,996 & 117.0 & 80.5 & 16.0 & 2.69E-03 & 3.1 \\
\hline Incineration & 4 & & & & & & & \\
\hline Fresh OFMSW & & 103 & 5,044 & 28.4 & 45.4 & 9.1 & 3.09E-04 & 0.8 \\
\hline SS-OFMSW refuse & & 8 & 392 & 2.2 & 3.5 & 0.7 & $2.40 \mathrm{E}-05$ & 0.1 \\
\hline NSS-OFMSW refuse & & 45 & 2,204 & 12.4 & 19.8 & 4.0 & $1.35 \mathrm{E}-04$ & 0.4 \\
\hline Collection and transport of fresh OFMSW & & 103 & 2,834 & 18.4 & 12.7 & 2.5 & 4.24E-04 & 0.5 \\
\hline Transport of SS-OFMSW \& NSS-OFMSW refuse & & 0 & & & & & & \\
\hline Sanitary Landfill & 29 & & & & & & & \\
\hline Fresh OFMSW & & 344 & 168,717 & 182.1 & 109.9 & 826.5 & $9.57 \mathrm{E}-04$ & 35.6 \\
\hline SS-OFMSW refuse & & 30 & 14,714 & 15.9 & 9.6 & 72.1 & $8.35 \mathrm{E}-05$ & 3.1 \\
\hline NSS-OFMSW refuse & & 65 & 31,880 & 34.4 & 20.8 & 156.2 & $1.81 \mathrm{E}-04$ & 6.7 \\
\hline Biostabilized material & & 100 & 1,203 & 52.9 & 31.9 & 240.3 & $2.78 \mathrm{E}-04$ & 10.4 \\
\hline Collection and transport of fresh OFMSW & & 344 & 25,628 & 162.7 & 116.3 & 24.0 & $3.85 \mathrm{E}-03$ & 4.2 \\
\hline Transport of SS-OFMSW \& NSS-OFMSW refuse & & 95 & 1,267 & 8.2 & 5.7 & 1.1 & $1.90 \mathrm{E}-04$ & 0.2 \\
\hline Transport of biostabilized materials & & 110 & 1,334 & 8.7 & 6.0 & 1.2 & $2.00 \mathrm{E}-04$ & 0.2 \\
\hline Total environmental impact $\left(\mathrm{t}_{\mathrm{IC}} \mathrm{y}^{-1}\right)$ & & 1218 & $3.56 \mathrm{E}+05$ & $9.98 \mathrm{E}+02$ & $1.37 \mathrm{E}+03$ & $1.50 \mathrm{E}+03$ & $1.4 \mathrm{E}-02$ & $4.37 \mathrm{E}+02$ \\
\hline Total environmental impact ( $\mathrm{t}_{\mathrm{IC}} \mathrm{Gg}^{-1}$ OFMSW) & & 1218 & $2.92 \mathrm{E}+02$ & 8.19E-01 & $1.13 \mathrm{E}+00$ & $1.23 \mathrm{E}+00$ & $1.16 \mathrm{E}-05$ & $3.59 \mathrm{E}-01$ \\
\hline
\end{tabular}


Table 4. Inventory data obtained from the installations considered in this study (AD: anaerobic digestion; CT: in-vessel composting; AWC: aerated windrows composting; TWC: turned windrows composting, HC: home composting) previously published in (Colón et al. 2012). AWB (aerated and turned windrows with gaseous emissions treatment) data have been theoretically calculated.

\begin{tabular}{|c|c|c|c|c|c|c|c|c|}
\hline Facility & Element & $\begin{array}{c}\text { Units } \\
\left(\mathrm{t}^{-1} \text { OFMSW }\right)\end{array}$ & $\begin{array}{c}\mathrm{AD} \& \\
\text { MSW-AD }\end{array}$ & $\begin{array}{c}\text { CT \& } \\
\text { MSW-CT }\end{array}$ & AWC & TWC & $\mathrm{HC}$ & AWB \\
\hline \multirow[t]{4}{*}{ Inputs } & Electricity & MJ & 166.32 & 770.4 & 235.8 & 33.41 & 33.77 & $354.8(119)^{*}$ \\
\hline & $\begin{array}{l}\text { Electricity self- } \\
\text { generation }\end{array}$ & MJ & 167.04 & 0 & 0 & 0 & 0 & 0 \\
\hline & Diesel & $\mathrm{L}$ & 3.64 & 2.66 & 9 & 5.33 & 0 & 9 \\
\hline & $\begin{array}{l}\text { Total enegry } \\
\text { (electricity + diesel) }\end{array}$ & MJ & 472.26 & 871.9 & $\begin{array}{c}579.2 \\
4\end{array}$ & 236.8 & 33.77 & 698.24 \\
\hline \multirow[t]{6}{*}{ Outputs } & $\mathrm{NH}_{3}$ emissions & $\mathrm{Kg}$ & 0.23 & 0.11 & 2 & 8.63 & 0.84 & $0.2(90)^{* *}$ \\
\hline & VOC emissions & $\mathrm{kg}$ & 0.86 & 0.75 & 6.22 & 5.7 & 0.56 & $1.87(70)^{* *}$ \\
\hline & $\mathrm{N}_{2} \mathrm{O}$ emissions & $\mathrm{Kg}$ & 0.035 & 0.085 & 0.076 & 0.251 & 0.676 & $0.076(0) * *$ \\
\hline & $\mathrm{CH}_{4}$ emissions & $\mathrm{Kg}$ & 2.39 & 0.15 & 1.68 & 4.37 & 0.16 & $1.51(10)^{* *}$ \\
\hline & Biogas production & $\mathrm{m}^{3}$ & 98.9 & $\mathrm{n} / \mathrm{a}$ & $\mathrm{n} / \mathrm{a}$ & $\mathrm{n} / \mathrm{a}$ & $\mathrm{n} / \mathrm{a}$ & $\mathrm{n} / \mathrm{a}$ \\
\hline & $\begin{array}{l}\text { Electricity } \\
\text { production }\end{array}$ & MJ & 550.08 & $\mathrm{n} / \mathrm{a}$ & $\mathrm{n} / \mathrm{a}$ & $\mathrm{n} / \mathrm{a}$ & $\mathrm{n} / \mathrm{a}$ & $\mathrm{n} / \mathrm{a}$ \\
\hline
\end{tabular}

* Value in brackets is the surplus of energy needed for the implementation of a gas treatment in AWB plants

** Values in brackets are the gas treatment removal efficiency considered in AWB plants 
Table 5. Impact potentials determined for OFMSW treatment plants representative of the treatment technologies implemented in Catalonia (Colón et al., 2012).

\begin{tabular}{|c|c|c|c|c|c|c|c|}
\hline \multirow[b]{2}{*}{ Treatment technology } & \multirow[b]{2}{*}{$\begin{array}{l}\text { Gaseous emissions } \\
\text { treatment }\end{array}$} & \multicolumn{6}{|c|}{ Impact potentials } \\
\hline & & $\begin{array}{c}\text { GWP } \\
\left(\mathrm{kg} \mathrm{CO}_{2} \text { eq }^{-1}\right)\end{array}$ & $\begin{array}{c}\text { ADP } \\
\left(\mathrm{kg} \mathrm{Sb} \text { eq t }^{-1}\right)\end{array}$ & $\begin{array}{c}\mathrm{AP} \\
\left(\mathrm{kg} \mathrm{SO}_{2} \mathrm{eq}^{-1}\right)\end{array}$ & $\begin{array}{c}\text { EUP } \\
\left(\mathrm{kg} \mathrm{PO}_{4}^{3-} \text { eq } \mathrm{t}^{-1}\right)\end{array}$ & $\begin{array}{c}\text { ODP } \\
\left(\mathrm{kg} \mathrm{CFC}-11 \mathrm{eq}^{-1}\right)\end{array}$ & $\begin{array}{c}\text { POP } \\
\left(\mathrm{kg} \mathrm{C}_{2} \mathrm{H}_{4} \text { eq t}^{-1}\right)\end{array}$ \\
\hline $\begin{array}{l}\text { Anaerobic Digestion } \\
\text { (AD \& MBT-AD) }\end{array}$ & $\begin{array}{l}\text { Wet scrubber + } \\
\text { biofilter }\end{array}$ & 45.2 & -0.16 & 0.16 & 0.07 & $-2.67 \mathrm{E}-07$ & 0.36 \\
\hline $\begin{array}{l}\text { In-vessel composting } \\
\text { (CT \& MBT-CT)* }\end{array}$ & $\begin{array}{c}\text { Wet scrubber }+ \\
\text { biofilter }\end{array}$ & 105.1 & 0.6 & 0.9 & 0.1 & $5.48 \mathrm{E}-06$ & 0.35 \\
\hline $\begin{array}{l}\text { Aerated windrows composting } \\
\text { (AWC) }\end{array}$ & No & 123 & 0.43 & 3.75 & 0.72 & $4.52 \mathrm{E}-06$ & 2.59 \\
\hline $\begin{array}{l}\text { Aerated windrow composting with } \\
\text { biofiltration (AWB) }\end{array}$ & Biofilter & 182 & 0.56 & 1.59 & 0.21 & $6.41 \mathrm{E}-06$ & 1.22 \\
\hline $\begin{array}{l}\text { Turned windrows composting } \\
\text { (TWC) }\end{array}$ & No & 196 & 0.14 & 14 & 3.03 & $2.37 \mathrm{E}-06$ & 2.38 \\
\hline Home composting (HC) & No & 209 & 0.04 & 1.4 & 0.3 & 3.05E-07 & 0.23 \\
\hline
\end{tabular}

* Average value from Colón et al., 2012 \& Martínez-Blanco et al., 2010

GWP: global warming potential; ADP: abiotic depletion potential; AP: acidification potential; EUP: eutrophication potential; ODP: ozone layer depletion potential; POP: photochemical oxidation potential 
Table 6: Comparison of the environmental impacts between the scenario ISc1 and the seven sensitivity analysis cases considered (ISc2-Isc8). Initial Isc1 is considered as the base scenario (100\% of contribution of each category), whereas the rest of sensitivity analysis cases are normalized to this base scenario.

\begin{tabular}{|c|c|c|c|c|c|c|c|c|c|}
\hline \multirow{2}{*}{$\begin{array}{l}\text { Impact } \\
\text { category }\end{array}$} & \multirow{2}{*}{$\begin{array}{c}\text { Units } \\
\left(\mathrm{Gg}^{-1} \mathrm{OFMSW}\right)\end{array}$} & \multirow{2}{*}{$\begin{array}{c}\text { Initial Scenario } \\
\text { ISc1 }\end{array}$} & \multicolumn{7}{|c|}{ Sensitivity analysis for other scenarios (\%) } \\
\hline & & & ISc2 & ISc3 & ISc4 & ISc5 & ISc6 & ISc7 & ISc8 \\
\hline GWP & $\left(\mathrm{t} \mathrm{CO}_{2} \mathrm{eq} \mathrm{y}^{-1}\right)$ & $3.56 \mathrm{E}+05$ & 82 & 94 & 105 & 109 & 136 & 98 & 95 \\
\hline ADP & $\left(\mathrm{t} \mathrm{Sb}\right.$ eq $\left.\mathrm{y}^{-1}\right)$ & $9.98 \mathrm{E}+02$ & 60 & 86 & 100 & 100 & 106 & n.a. & n.a. \\
\hline AP & $\left(\mathrm{t} \mathrm{SO}_{2} \mathrm{eq} \mathrm{y}^{-1}\right)$ & $1.37 \mathrm{E}+03$ & 80 & 93 & 100 & 100 & 106 & n.a. & n.a. \\
\hline $\mathrm{EP}$ & $\left(\mathrm{tPO}_{4}{ }^{3-}\right.$ eq $\left.\mathrm{y}^{-1}\right)$ & $1.50 \mathrm{E}+03$ & 96 & 99 & 100 & 100 & 100 & n.a. & n.a. \\
\hline OLDP & $\left(\mathrm{t}\right.$ CFC-11 eq $\left.\mathrm{y}^{-1}\right)$ & $1.41 \mathrm{E}-02$ & 34 & 77 & 100 & 100 & 114 & n.a. & n.a. \\
\hline POP & $\left(\mathrm{t} \mathrm{C}_{2} \mathrm{H}_{4} \mathrm{eq} \mathrm{y}^{-1}\right)$ & $4.37 \mathrm{E}+02$ & 98 & 99 & 101 & 102 & 108 & n.a. & n.a. \\
\hline
\end{tabular}

ISc2: Transport not included

ISc3: Average distance from collection points to SS-OFMSW treatment facilities is $5 \mathrm{~km}$ and the average distance to landfills is $10 \mathrm{~km}$

ISc4: methane fugitive emissions (5\%) are included in AD \& MSW-AD treatment plants

ISc5: methane fugitive emissions $(10 \%)$ are included in AD \& MSW-AD treatment plants

ISc6: landfill biogas collection decreased to $17 \%$

ISc7: Compost is used as organic amendment

ISc8: Compost and biostabilized material coming from NSS-OFMSW treatment are used as organic amendment n.a: not analyzed 
Table 7. Total and partial impact results for Scenario LDSc1.

\begin{tabular}{|c|c|c|c|c|c|c|c|}
\hline & $\begin{array}{l}\text { Treated } \\
\text { OFMSW } \\
\left(\mathrm{Gg} \mathrm{y}^{-1}\right)\end{array}$ & $\begin{array}{c}\text { GWP } \\
\left(\mathrm{t} \mathrm{CO}_{2} \mathrm{eq} \mathrm{y}^{-1}\right)\end{array}$ & $\begin{array}{c}\text { ADP } \\
\left(\mathrm{t} \mathrm{Sb} \mathrm{eq} \mathrm{y}^{-1}\right)\end{array}$ & $\begin{array}{c}\mathrm{AP} \\
\left(\mathrm{t} \mathrm{SO}_{2} \mathrm{eq} \mathrm{y}^{-1}\right)\end{array}$ & $\begin{array}{c}\text { EUP } \\
\left(\mathrm{t} \mathrm{PO}_{4}^{3-} \text { eq } \mathrm{y}^{-}\right. \\
\left.{ }_{1}\right)\end{array}$ & $\begin{array}{c}\text { OLDP } \\
\left(\begin{array}{c}\text { ( CFC-11 eq } y^{-} \\
1\end{array}\right)\end{array}$ & $\begin{array}{c}\text { POP } \\
\left(\mathrm{t} \mathrm{C}_{2} \mathrm{H}_{4} \text { eq }^{-1}\right)\end{array}$ \\
\hline \multicolumn{8}{|l|}{ Source-selected OFMSW } \\
\hline Anaerobic Digestion (AD) & 525 & 22,600 & -80.0 & 80.0 & 35.0 & $-1.34 \mathrm{E}-04$ & 180.0 \\
\hline In-vessel composting $(\mathrm{CT})$ & 135 & 13,139 & 75.4 & 112.2 & 9.1 & $6.84 \mathrm{E}-04$ & 44.1 \\
\hline Aerated windrows composting (AWB) & 45 & 14,742 & 45.4 & 128.8 & 17.0 & $5.19 \mathrm{E}-04$ & 98.8 \\
\hline Home composting (HC) & 25 & 5,225 & 1.0 & 35.0 & 7.5 & 7.63E-06 & 5.8 \\
\hline Collection and transport & 705 & 28,835 & 187.5 & 129.0 & 25.7 & $4.315 \mathrm{E}-03$ & 4.9 \\
\hline \multicolumn{8}{|l|}{ Non Source-selected OFMSW (from mixed MSW) } \\
\hline Anaerobic Digestion (MSW-AD) & 0 & 0 & 0.0 & 0.0 & 0.0 & $0.00 \mathrm{E}+00$ & 0.0 \\
\hline In-vessel composting (MSW-CT) & 487 & 51,189 & 293.6 & 437.1 & 35.6 & $2.67 \mathrm{E}-03$ & 171.9 \\
\hline Collection and transport & 487 & 19,918 & 129.5 & 89.1 & 17.7 & $2.98 \mathrm{E}-03$ & 3.4 \\
\hline \multicolumn{8}{|l|}{ Incineration } \\
\hline Fresh OFMSW & 0 & 0 & 0.0 & 0.0 & 0.0 & $0.00 \mathrm{E}+00$ & 0.0 \\
\hline SS-OFMSW refuse & 15 & 735 & 4.1 & 6.6 & 1.3 & $4.50 \mathrm{E}-05$ & 0.1 \\
\hline NSS-OFMSW refuse & 50 & 2,449 & 13.8 & 22.0 & 4.4 & $1.50 \mathrm{E}-04$ & 0.4 \\
\hline Collection and transport of fresh OFMSW & 103 & 2,834 & 18.4 & 12.7 & 2.5 & 4.24E-04 & 0.5 \\
\hline Transport of SS-OFMSW \& NSS-OFMSW refuse & 0 & & & & & & \\
\hline \multicolumn{8}{|l|}{ Sanitary Landfill } \\
\hline Fresh OFMSW & 0 & 0 & 0.0 & 0.0 & 0.0 & $0.00 \mathrm{E}+00$ & 0.0 \\
\hline SS-OFMSW refuse & 56 & 27,466 & 29.6 & 17.9 & 134.6 & $1.56 \mathrm{E}-04$ & 5.8 \\
\hline NSS-OFMSW refuse & 72 & 35,313 & 38.1 & 23.0 & 173.0 & $2.00 \mathrm{E}-04$ & 7.5 \\
\hline Biostabilized material & 121 & 1,456 & 64.1 & 38.7 & 290.7 & $3.37 \mathrm{E}-04$ & 12.5 \\
\hline Collection and transport of fresh OFMSW & 0 & 0 & 0.0 & 0.0 & 0.0 & $0.00 \mathrm{E}+00$ & 0.0 \\
\hline Transport of SS-OFMSW \& NSS-OFMSW refuse & 95 & 1,267 & 8.2 & 5.7 & 1.1 & $1.90 \mathrm{E}-04$ & 0.2 \\
\hline Transport of biostabilized materials & 121 & 1,614 & 10.5 & 7.2 & 1.4 & $2.42 \mathrm{E}-04$ & 0.3 \\
\hline Total environmental impact $\left(\mathrm{t}_{\mathrm{IC}} \mathrm{y}^{-1}\right)$ & 1218 & $2.29 \mathrm{E}+05$ & $8.39 \mathrm{E}+02$ & $1.14 \mathrm{E}+03$ & $7.57 \mathrm{E}+02$ & $1.28 \mathrm{E}-02$ & $5.36 \mathrm{E}+02$ \\
\hline Total environmental impact ( $\mathrm{t}_{\mathrm{IC}} \mathrm{Gg}^{-1}$ OFMSW) & 1218 & $1.88 \mathrm{E}+02$ & $6.89 \mathrm{E}-01$ & $9.40 \mathrm{E}-01$ & $6.21 \mathrm{E}-01$ & $1.05 \mathrm{E}-05$ & $4.40 \mathrm{E}-01$ \\
\hline
\end{tabular}


Table 8: Comparison of the environmental impacts between the scenario LDSc1 and the nine sensitivity analysis cases (LDSc2-LDSc10). Scenario LDSc1 is considered as the base scenario (100\% of contribution of each category), whereas the rest of sensitivity analysis cases are normalized to this base scenario impact.

\begin{tabular}{|c|c|c|c|c|c|c|c|c|c|c|c|}
\hline \multirow{2}{*}{$\begin{array}{l}\text { Impact } \\
\text { category }\end{array}$} & \multirow{2}{*}{$\begin{array}{c}\text { Units } \\
\left(\mathrm{Gg}^{-1} \text { OFMSW }\right)\end{array}$} & \multirow{2}{*}{$\begin{array}{c}\text { Initial Scenario } \\
\text { LDSc1 }\end{array}$} & \multicolumn{9}{|c|}{ Sensitivity analysis for other scenarios (\%) } \\
\hline & & & LDSc2 & LDSc3 & LDSc4 & LDSc5 & LDSc6 & LDSc7 & LDSc8 & LDSc9 & $\begin{array}{c}\text { LDSc } 1 \\
0\end{array}$ \\
\hline GWP & $\left(\mathrm{t} \mathrm{CO}_{2}{\left.\text { eq } \mathrm{y}^{-1}\right)}^{-1}\right.$ & $2.29 \mathrm{E}+05$ & 75 & 101 & 108 & 118 & 131 & 117 & 96 & 93 & 88 \\
\hline $\mathrm{ADP}$ & $\left(\mathrm{t} \mathrm{Sb} \mathrm{eq} \mathrm{y}^{-1}\right)$ & $8.39 \mathrm{E}+02$ & 56 & 105 & 128 & 100 & 100 & 101 & 97 & n.a. & n.a. \\
\hline AP & $\left(\mathrm{t} \mathrm{SO}_{2} \mathrm{eq}^{-1}\right)$ & $1.14 \mathrm{E}+03$ & 78 & 104 & 120 & 100 & 100 & 101 & 97 & n.a. & n.a. \\
\hline EP & $\left(\mathrm{tPO}_{4}{ }^{3-} \mathrm{eq} \mathrm{y}^{-1}\right)$ & $7.57 \mathrm{E}+02$ & 93 & 100 & 100 & 100 & 100 & 100 & 100 & n.a. & n.a. \\
\hline OLDP & $\left(\mathrm{t} \mathrm{CFC}-11\right.$ eq $\left.\mathrm{y}^{-1}\right)$ & $1.28 \mathrm{E}-02$ & 35 & 101 & 114 & 100 & 100 & 102 & 95 & n.a. & n.a. \\
\hline POP & $\left(\mathrm{t} \mathrm{C}_{2} \mathrm{H}_{4} \mathrm{eq} \mathrm{y}^{-1}\right)$ & $5.36 \mathrm{E}+02$ & 98 & 100 & 100 & 102 & 103 & 101 & 99 & n.a. & n.a. \\
\hline
\end{tabular}

LDSc2: Transport not included

LDSc3: New designed SS-OFMSW facilities uses CT technology instead of AD technology

LDSc4: All the extra SS-OFMSW is treated by means of CT technology (AD treats the same amount as in ISc1)

LDSc5: methane fugitive emissions (5\%) are included in AD treatment plants

LDSc6: methane fugitive emissions $(10 \%)$ are included in AD treatment plants

LDSc7: landfill biogas collection decreased to $17 \%$

LDSc8: landfill biogas collection increased up to $60 \%$

LDSc9: Compost is used as organic amendment

LDSc10: Compost and biostabilizaed material coming from NSS-OFMSW treatment are used as organic amendment

n.a: not analyzed 


\section{Figure Captions}

Fig 1 Waste treatment scenarios considered in this study. 1a) Current scenario (ISc1) and 1b) future scenario fulfilling the European Landfill Directive (LDSc1).

Fig 2. Existing waste treatment and disposal installations in Catalonia in 2012 and their geographic distribution.

Fig 3 Fig 3.a Contribution (in percentage) of the items considered in scenario ISc1 to its total environmental impact. Figure 3b, contribution (in percentage) of the items considered (transport excluded) in scenario ISc1 to its total environmental impact. Impact categories: GWP, global warming potential; ADP, abiotic depletion potential; AP, acidification potential; EP, eutrophication potential; OLDP, ozone layer depletion potential; POP, photochemical oxidation potential; CED, cumulative energy demand.

Fig 4 Fig 4.a Contribution (in percentage) of the items considered in scenario LDSc1 to its total environmental impact. Figure 4b, contribution (in percentage) of the items considered (transport excluded) in scenario LDSc1 to its total environmental impact. Impact categories: GWP, global warming potential; ADP, abiotic depletion potential; AP, acidification potential; EP, eutrophication potential; OLDP, ozone layer depletion potential; POP, photochemical oxidation potential; CED, cumulative energy demand.

Fig 5 Comparison of the total environmental impacts of the two proposed scenarios: ISc1 and LDSc1. 
Figure 1

1a)

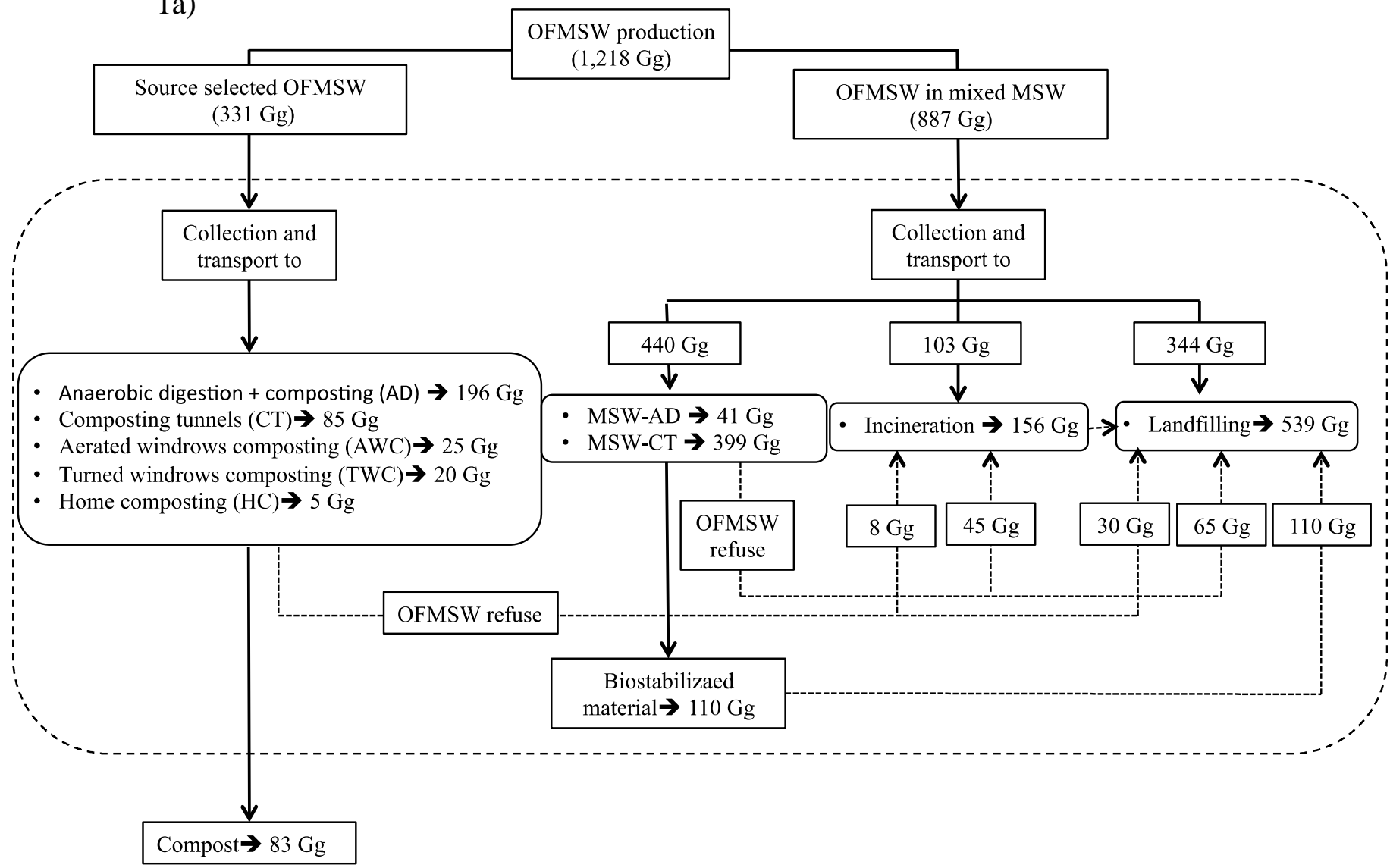

1b)

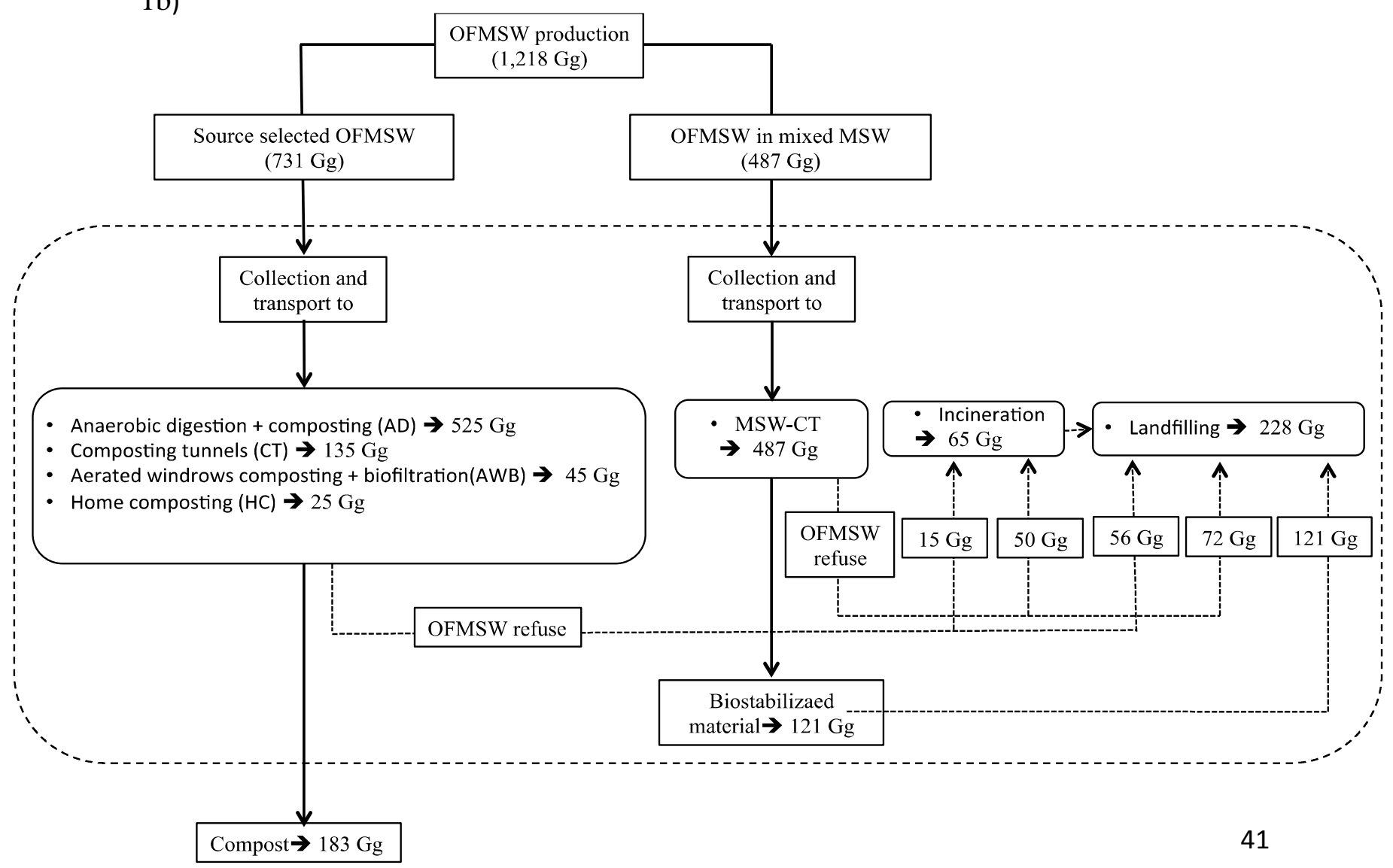


Figure 2

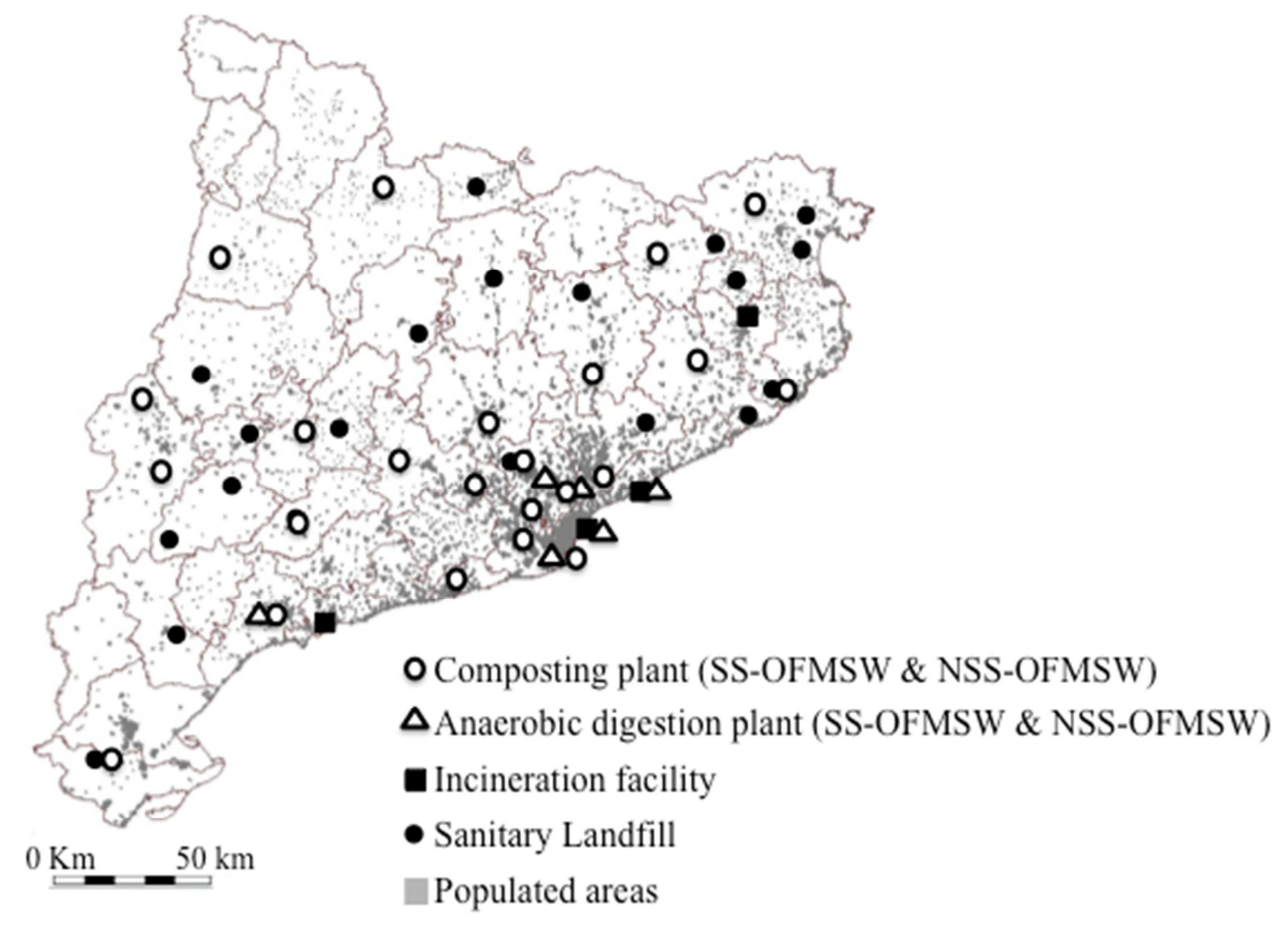


Figure 3

3.a)

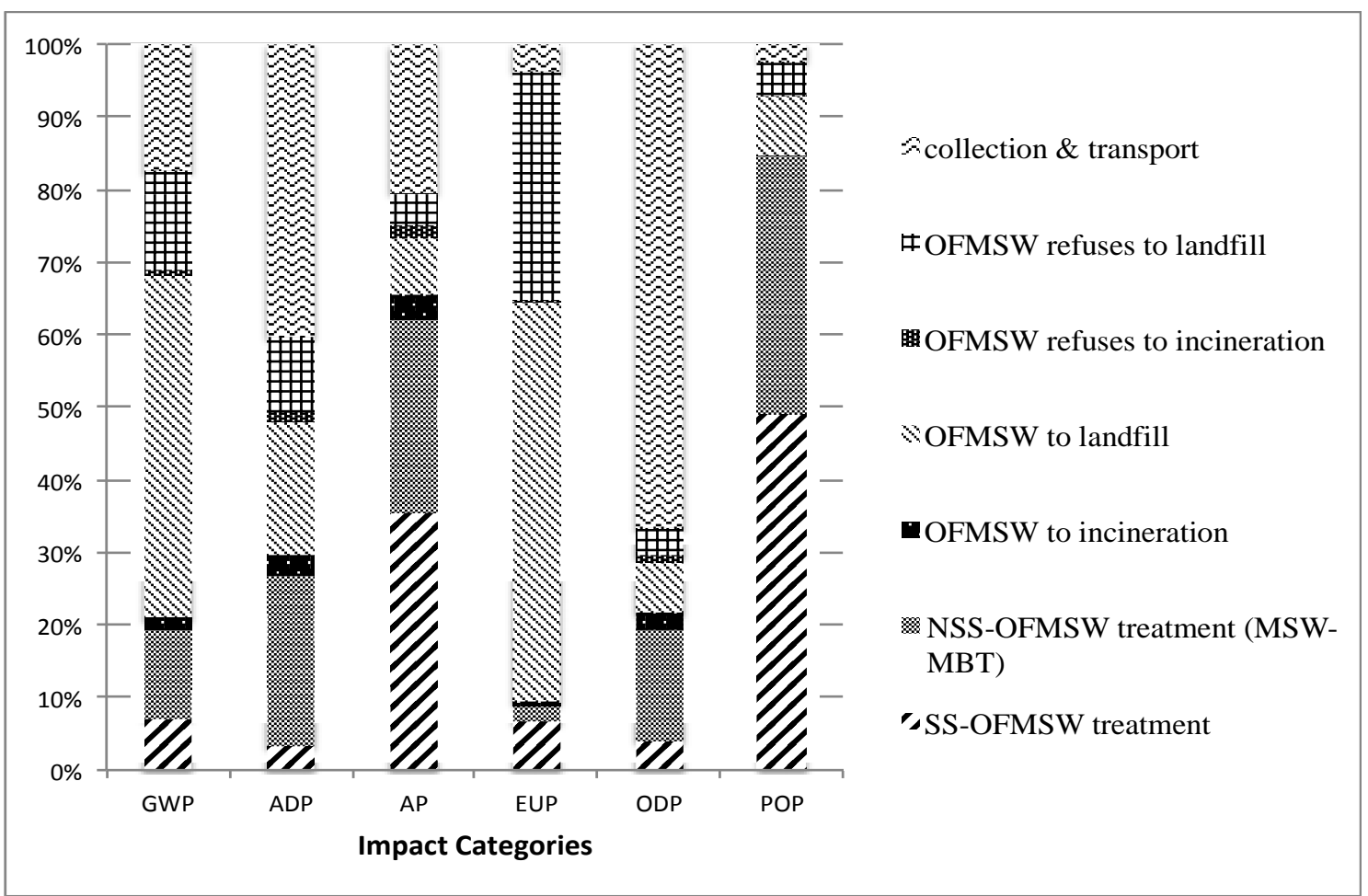

3.b)

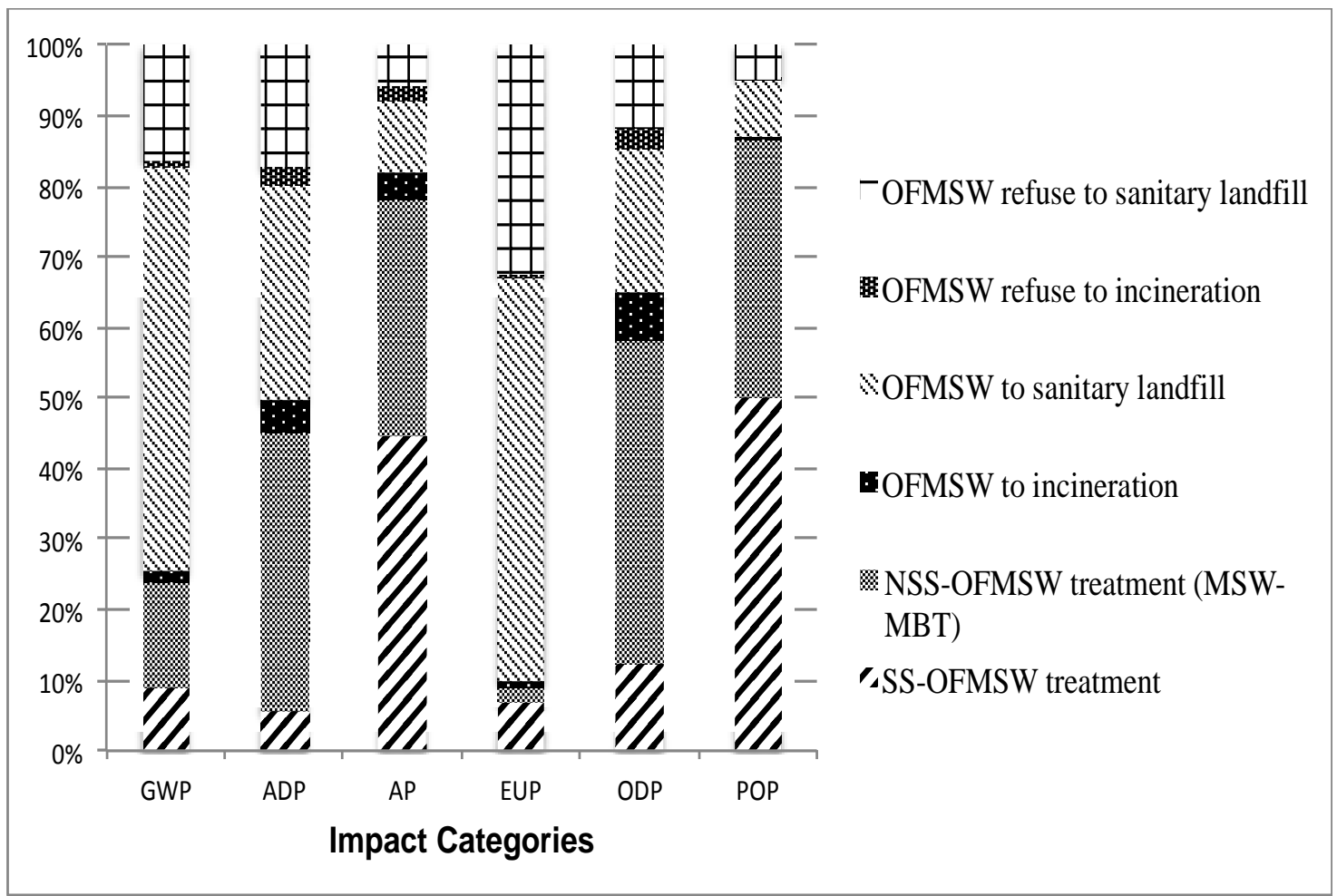


Figure 4

4.a)

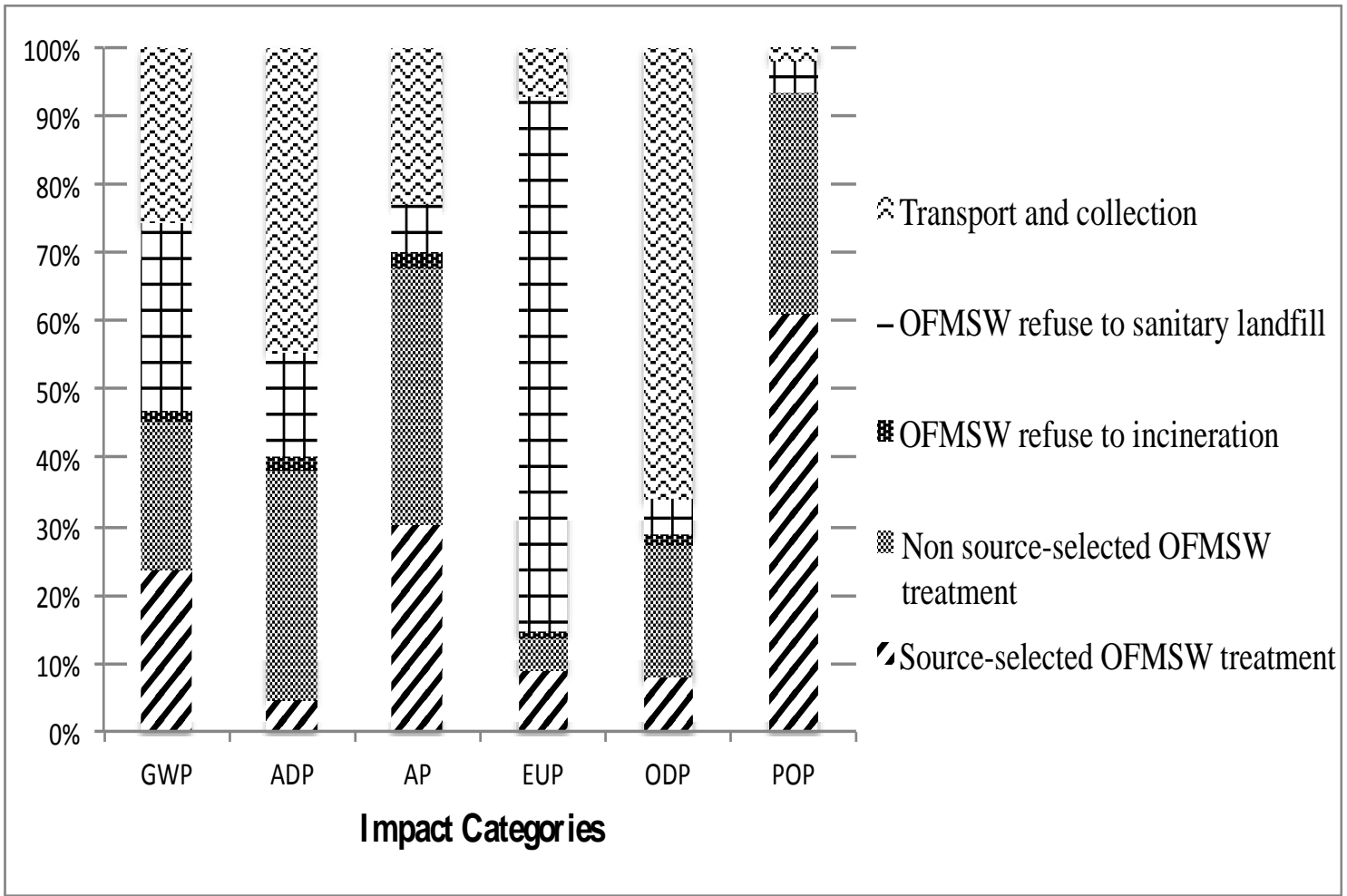

4.b)

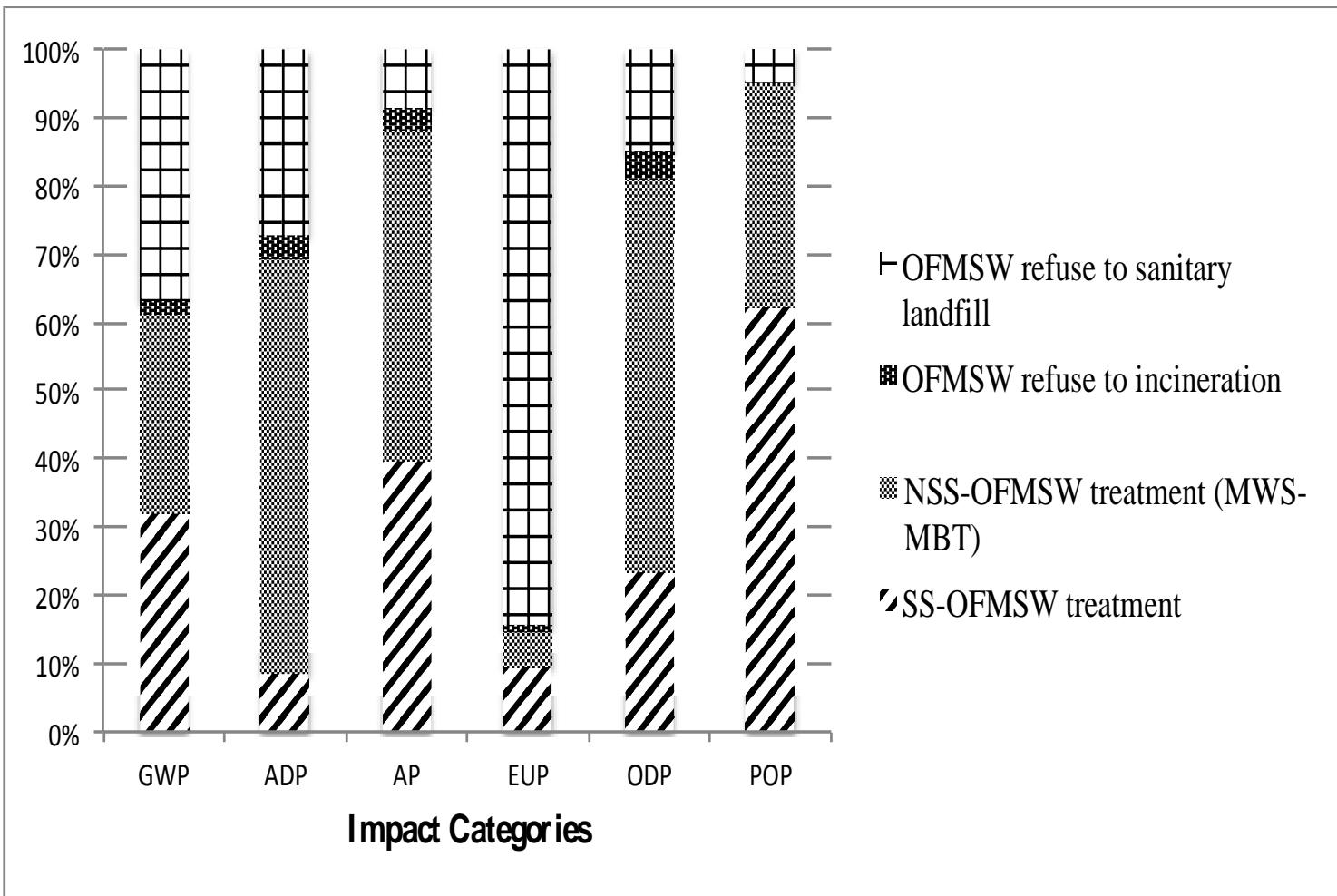


Figure 5
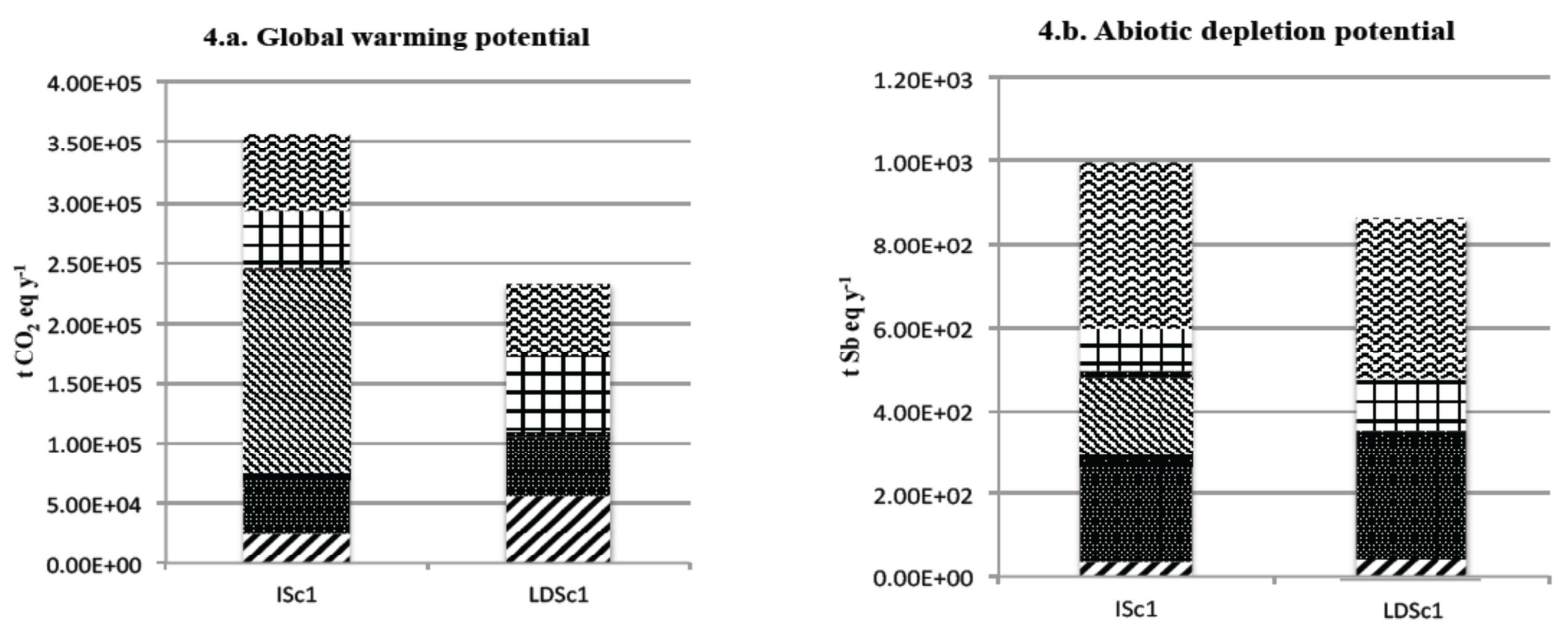

4.c. Acidification potential
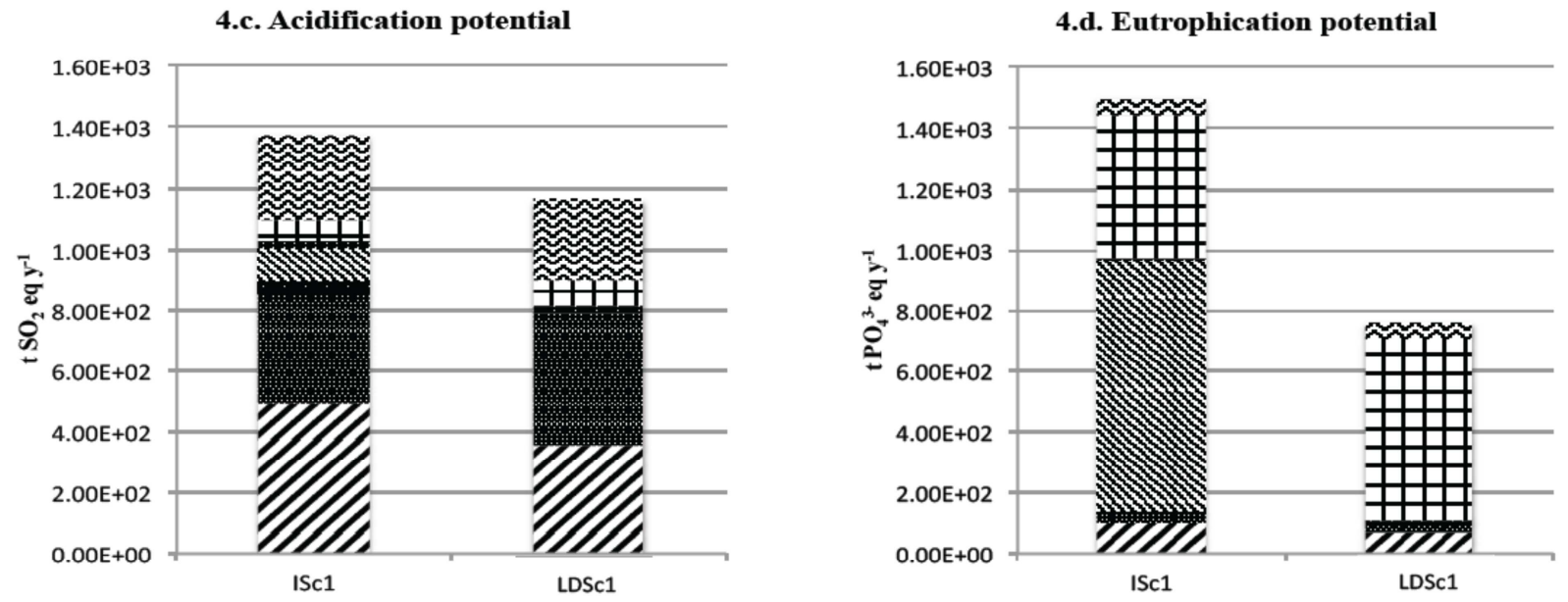

4.d. Eutrophication potential

4.e. Ozone layer depletion potential
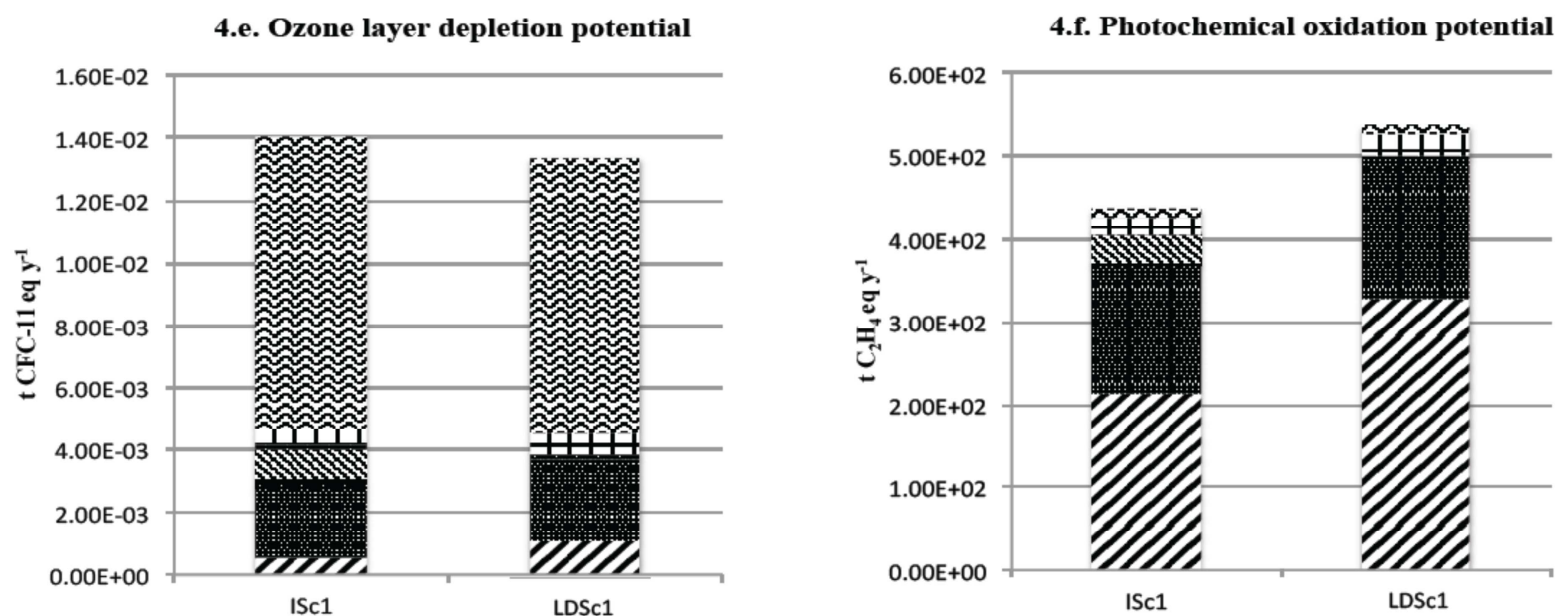
1 Source-selected OFMSW treatment
Non source-selected OFMSW treatment

- OFMSW to incineration NOFMSW to sanitary landfill

B OFMSW refuse to incineration $\leftarrow$ OFMSW refuse to sanitary landfill $\quad$ \% Transport and collection 